\title{
Adoption in the Conflict of Laws: The UAA, Not the UCCJA, Is the Answer
}

\author{
Herma Hill Kay $\dagger$
}

In recent years a number of courts in adoption cases have resolved interstate jurisdictional disputes using the Uniform Child Custody Jurisdiction Act (UCCJA). This Article contends that the UCCJA was never intended to be applied in adoption cases, but rather was crafted specifically to meet the very different requirements of child custody disputes following the dissolution of a marriage. Specifically, the UCCJA is designed for situations in which custody determinations are not final judgments and so can be modified to meet changed circumstances. Adoption orders, by contrast, are final judgments, and as such are entitled to full faith and credit in the courts of other states. This Article argues that the proper model for dealing with interstate jurisdictional issues in adoption cases is the Uniform Adoption Act (UAA), which is carefully designed for this purpose. The Article urges state legislatures to enact the UAA, with suggested modifications. Further, the Article urges state courts to begin using the Full Faith and Credit Clause to resolve interstate adoption problems, rather than waiting for legislative action. By continuing to apply the UCCJA in adoption cases, the Article argues, courts risk damage both to the parties in those cases and to the underlying substantive law.

\section{INTRODUCTION}

In July of 1993, Time magazine ran a cover photo of a two-and-ahalf-year-old girl known as "Baby Jessica," who had been caught in a struggle between her adoptive and biological parents.' The legal contest had stretched across two states and lasted more than two years, at least in part because the courts in those states misconstrued the conflict of laws problems inherent in the case. Specifically, the courts applied one

Copyright $\odot 1996$ California Law Review, Inc.

$\dagger$ Richard W. Jennings Professor of Law, Boalt Hall School of Law, University of California, Berkeley. B.A. 1956, Southern Methodist University; J.D. 1959, University of Chicago. I am grateful to Professor Joan Hollinger, Reporter for the Uniform Adoption Act, for her comments on a draft of this Article.

1. Nancy Gibbs, In Whose Best Interest?, Time, July 19, 1993, at 44, 47. 
statute-the Uniform Child Custody Jurisdiction Act (UCCJA) ${ }^{2}$-that was not designed for use in the adoption context, and they failed to make proper use of a constitutional provision-the Full Faith and Credit Clause $^{3}$ - that would greatly have eased Baby Jessica's ordeal. It is unfortunate that the courts in Baby Jessica's case so misinterpreted the constitutional and statutory tools at their disposal. It is dismaying that those courts were repeating the errors of earlier courts and that, since 1993, courts have continued to make the same mistakes. In part, the earlier mistakes can be charged to the fact that no readily available solution to the problem of interstate adoption was at hand, and the courts seized upon a widely enacted piece of model legislation drafted to deal with a different problem-interstate child custody cases-as the solution to their interstate adoption problems as well. But the UCCJA simply is not the answer to the problems of interstate adoption. Rather, the appropriate model statute for state legislators to enact, and then for judges to apply, is the Uniform Adoption Act (UAA). ${ }^{4}$ This model legislation, promulgated in 1994 and available for consideration by the states, specifically addresses the problems that Baby Jessica faced, and offers the best hope that situations like hers may be avoided in the future.

Those situations are by now, with the further cases of "Baby Richard" and others, all too familiar. A child is born to a single woman who releases the child for adoptive placement without giving notice of her action to the child's birth father. The child is placed with prospective adoptive parents who are unrelated to the birth parents. After the placement, but before a court order is entered determining the child's status, the birth father asserts his paternity and demands that the child be turned over to him. Or, in an alternative scenario, the birth mother changes her mind, withdraws her consent to the adoption, and seeks to have the child returned to her. In either case, the prospective adoptive parents refuse. A court enters a judgment denying the adoption and ordering the child returned to the birth parent. Instead of complying, the prospective adoptive parents start over again in another state in the hope of doing better the secoud time around.

These situations threaten psychological injury to the children involved and pose difficult, even traumatic, problems in the substantive law of adoption, where the conditions under which a birth mother may withdraw her consent and a birth father may prevent an adoption are sharply contested. In that part of the jurisprudence of conflict of laws touching the recognition of sister-state judgments, however, the notion is

\footnotetext{
2. 9 U.L.A. pt. 1, at 115 (1988).

3. U.S. CoNST. art. IV, $\S 1$.

4. 9 U.L.A. pt. 1, at 1 (Supp. 1995).
} 
uncontroversial that a final judgment binding on parties subject to the court's jurisdiction is entitled to full faith and credit in other states. Under state law, a court order granting or denying an adoption, unlike a custody proceeding following a divorce or separation, is just such a final judgment. Yet, as this Article will show, the clarity of the conflicts aspects of interstate adoption law has been lost in a misguided effort by a majority of the state courts that have ruled on the matter to apply the UCCJA, a statute drafted to resolve interstate divorce child-custody cases, to the very different jurisdictional problems of adoption cases.

Fortunately, the National Conference of Commissioners on Uniform State Laws, the body that drafted the UCCJA, has now promulgated a model statute that expressly addresses both the substantive and procedural aspects of adoption cases: the UAA. This Article argues that, with a few significant modifications, the UAA can satisfactorily resolve the conflicts aspects of interstate adoptions. The Article therefore calls upon state legislatures to enact the UAA with the changes proposed in Parts III and IV.

The Article further recommends that state courts should not await legislative action to correct their false steps. For one thing, there is no gnarantee that all-or even most-states will pass the UAA anytime soon. ${ }^{5}$ More importantly, by continuing to misapply the UCCJA, courts risk causing substantial damage both to the statute and to the underlying substantive law. Consequently, this Article maintains that courts should immediately cease their inappropriate reliance on the UCCJA in interstate adoption cases.

In Part I, this Article presents two well-known adoption cases featuring a common problem: the birth father's objection to the adoption of a child placed by the birth mother without his knowledge or consent. In both cases, the courts sustained the father's objection and denied the adoption. One of these cases became an interstate problem because of the losing parties' effort to secure a more favorable adjudication in a different state. The other case remained confined within a single state, but it, too, featured an attempt by the prospective adoptive parents to invoke a law designed for a different situation-child custody proceedings following divorce-to avoid the unfavorable outcome indicated by the law of adoption. In both cases, the losing party sought to persuade the court to equate an adoption proceeding with a "child custody proceeding" as that term is used in divorce and separation cases. Both courts partially accepted this evasionary tactic, agreeing that an adoption proceeding was "a custody proceeding." They nonetheless managed

5. The UAA was promulgated in 1994 and has not yet been adopted by any state. Prior efforts to achieve more uniformity in adoption have faltered. See Joan H. Hollinger, Adoption Law, THE Future OF CHILDREN, Spring 1993, at $43,46$. 
to avoid disturbing the prior judgments, thereby denying the tactic its intended effect, but only at the unacceptable cost of engaging in incoherent reasoning.

Furthermore, the courts' opinions lend precedential weight to the equation of "adoption" and "custody" proceedings. The logic of such an equation would not only jeopardize sound results under the substantive law of adoption, but would also serve to blur the distinction between related, but sharply different, bodies of law. Laws addressing adoption are, and should remain, distinct from laws dealing with the custody of children following marital dissolution.

In Part II, this Article explores how state courts have mistakenly applied the UCCJA and its federal implementing statute, the Parental Kidnapping Prevention Act (PKPA), ${ }^{6}$ to a subject neither was designed to cover: interstate adoptions. Once this misinterpretation has been clarified, the Article undertakes a fresh analysis, in Part III, of the conflict of laws problems of jurisdiction-including personal jurisdiction over nonconsenting birth parents-and recognition of judgments in interstate adoption cases. Finally, this Article reviews, in Part IV, the conflict of laws provisions of the UAA, suggests modifications to address some problems not fully resolved in the Act, and concludes that, as modified, the Act would go far toward alleviating some of the most acute problems of interstate adoption.

I

\section{The Cases of Baby Jessica and Baby Richard}

In the winter months of 1991, two infants destined to make legal and social history were born to unmarried women. Baby Jessica was born on February 8, 1991, to Cara Clausen in Iowa. ${ }^{7}$ Baby Richard was born on March 16, 1991, to Daniella Janikova in Illinois. ${ }^{8}$ Concealing their actions from the children's respective fathers, both mothers placed their babies for adoption. Baby Jessica went to Michigan to live with Roberta and Jan DeBoer, who filed a petition for her adoption in juvenile court in Iowa on February 25, 1991. ${ }^{9}$ Baby Richard was placed as a

6. Pub. L. No. $96-611, \S \S 6-10,94$ Stat. 3568 (1980) (codified in relevant part at 28 U.S.C. $\S$ 1738A (1994)).

7. In re B.G.C., 496 N.W.2d 239, 240 (Iowa 1992).

8. In re Doe, 627 N.E.2d 648, 649-50 (11l. App. Ct. 1993), rev'd, 638 N.E.2d 181 (Ill. 1994), cert. denied, 115 S. Ct. 499 (1994).

9. In re Clausen, 501 N.W.2d 193, 194 (Mich. Ct. App.), aff'd, 502 N.W.2d 649 (Mich.), stay denied sub nom. DeBoer by Darrow v. DeBoer, 114 S. Ct. 1 (Stevens, J.), and stay denied, 114 S. Ct. 11 (1993). 
newborn with Kimberly and Robert Warburton, ${ }^{10}$ who filed a petition for his adoption in Cook County, Illinois, on March 20, 1991."

Subsequently, each father learned about the baby's birth, discovered that the child's mother had placed the child for adoption, and took action to assert his legal rights. ${ }^{12}$ Ultimately, both fathers were found not to have relinquished their rights, and both were found to be fit parents.

The adoption petitions were denied, and both sets of prospective adoptive parents were ordered to return the children to their birth parents, who had married during the proceedings. ${ }^{13}$ In both cases, the prospective adoptive parents refused to comply. Instead, they sought other legal avenues for raising the question whether the return would be in the child's "best interests."

In Baby Richard's case, the Warburtons found a singularly inappropriate source of authority to hold a "custody proceeding": the Illinois Marriage and Dissolution of Marriage Act. ${ }^{15}$ The Illinois Supreme B7.

10. Adoptive Parents Are Rebuffed by High Court in Last Plea, N.Y. TimEs, June 20, 1995, at

11. In re Doe, 627 N.E.2d at 650 .

12. Cara Clausen had falsely named Scott Seefeldt as Baby Jessica's father. In re Clausen, 502 N.W.2d at 652 . On February 25, 1991, a juvenile court in Iowa terminated the parental rights of both Cara and Scott. Id. Soon thereafter, Daniel Schmidt, Jessica's biological father, learned of her birth from Cara. In re B.G.C., 496 N.W.2d at 241. On March 6, Cara moved to revoke her release of custody. In re Clausen, 502 N.W.2d at 652 . Later that month, Daniel filed an affidavit of paternity and petitioned to intervene in the adoption proceedings, objecting to the adoption on the ground that he had not relinquished his paternal rights to his daughter. In re Clausen, 501 N.W.2d at 194.

Daniella Janikova refused to disclose the name of Baby Richard's father, Otakar Kirchner, to the Warburtons or their lawyer. In re Doe, 627 N.E.2d at 650 . At Daniella's request, her uncle told Otakar that the baby had been born dead. Id. Otakar refused to believe this story and eventually learned from a mutual friend that the baby had been born alive and relinquished for adoption. Id. He consulted an attorney, and on June 6,1991, he filed an appearance in the adoption proceedings. Id. at 651 .

13. Otakar and Daniella married in September 1991. In re Doe, 627 N.E.2d at 651; Daniel and Cara married in April 1992. In re Clausen, 502 N.W.2d at 652 n.6.

14. For an overview and a critique of the "best interests" standard, see Robert H. Mnookin, Child-Custody Adjudication: Judicial Functions in the Face of Indeterminacy, 39 LAw \& CoNTEMP. PROBS. 226 (1975).

15. 750 Ill. Comp. Stat. ANn. 5/601(b)(2) (West 1993 \& Supp. 1995):

(b) A child custody proceeding is commenced in the court: ... (2) by a person other than a parent, by filing a petition for custody of the child in the county in which he is permanently resident or found, but only if he is not in the physical custody of one of his parents.

The Warburtons also invoked an amendment to the 1llinois Adoption Act that had been enacted to overrule the court's decision in Baby Richard's case. That amendment provides:

In the event that an order for adoption is vacated, the court shall promptly conduct a hearing as to the temporary and permanent custody of the minor child who is the subject of the proceeding pursuant to Part VI of the Illinois Marriage and Dissolution of Marriage Act. The parties to the proceeding shall be the petitioners to the adoption proceeding, the minor child, the biological parents whose rights have been terminated, and other parties who have been granted leave to intervene in the proceeding.

Pub. Act 88-550, art. 9, § 975 (effective July 3, 1994) (codified at 750 lLl. Comp. Stat. ANN. 50/20b (West Supp. 1995) (footnote omitted). The Illinois Supreme Court refused to apply the amendment 
Court held that this avenue was blocked because "[a] nonparent may only assert standing under [the Act] if the natural parent at issue does not have physical custody of his or her child."' The court went on to explain that, while the Warburtons retained "physical possession" of Baby Richard, he was not in their "physical custody":

In simple terms, Richard is in the Does' home without color of right. The Does' sole claim to custody of Richard was invalidated by this court on June 16,1994, when their invalid adoption of Richard was vacated. Since that date, the Does have retained physical possession of Richard but not his custody for purposes of [the Act]. ${ }^{17}$

In Baby Jessica's case, the DeBoers attempted to use the UCCJA to confer jurisdiction on the Michigan courts to conduct a "custody proceeding." They sought such a proceeding despite the fact that a final judgment, entitled to full faith and credit, had already been reached in the Iowa adoption proceeding. That is, the DeBoers' petition for adoption, filed in the Iowa court, had been denied, and they had been ordered to return Jessica to her birth parents. The Iowa Supreme Court had affirmed the district court's judgment denying the adoption because Daniel Schmidt had proved that he was the father and that he had not abandoned his daughter..$^{18}$ Accordingly, the district court had entered an order on December 3, 1992, terminating the DeBoers' rights as temporary guardians and custodians of the child. ${ }^{19}$

Notwithstanding this order, on the same day, the DeBoers filed a petition in a Michigan circuit court asking that court to assume jurisdiction under the UCCJA. ${ }^{20}$ They petitioned the court either to enjoin the enforcement of the Iowa order, or to inodify it by holding a "best interests" child custody hearing and awarding custody of Baby Jessica to them. ${ }^{21}$ The court entered an ex parte temporary restraining order, directing that the child remain in the DeBoers' custody and ordering Schmidt not to remove the child from Michigan. Daniel Schmidt countered on December 11 with a motion for suminary judgment, ask-

retroactively on the ground that to do so would violate the principle of separation of powers embodied in Article II, Section 1 of the Illinois Constitution of 1970. In re Kirchner, 649 N.E.2d 324, 336-38 (III.), cert. denied, 115 S. Ct. 2599, and cert. denied, 115 S. Ct. 2600 (1995).

16. In re Kirchner, 649 N.E.2d at 335.

17. Id. In the quoted passage, the "Does" are the Warburtons.

18. In re B.G.C., 496 N.W.2d 239, 241 (lowa 1992).

19. In re Clausen, 502 N.W.2d 649, 653 (Mich.), stay denied sub nom. DeBocr by Darrow v. DeBoer, 114 S. Ct. 1 (Stevens, J.), and stay denied, 114 S. Ct. 1 I (1993). At the time of this order, Baby Jessica was not yet two years old.

20. In re Clausen, 501 N.W.2d 193, 195 (Mich. Ct. App.) (dcscribing the DeBoers' argument that Michigan was Jessica's "home state" because she had lived there for all but approximately three weeks of her life), affd, 502 N.W.2d 649 (Mich.), stay denied sub nom. DeBoer by Darrow v. DeBoer, 114 S. Ct. 1 (Stevens, J.), and stay denied, 14 S. Ct. 11 (1993).

21. In re Clausen, 502 N.W.2d at 653 . 
ing that the Michigan court dissolve the preliminary injunction and recognize and enforce the Iowa judgment under the UCCJA ${ }^{22}$ and the Full Faith and Credit Clause. ${ }^{23}$

The circuit court assumed jurisdiction to hold a custody proceeding to determine the best interests of Baby Jessica. Its hearing on that matter lasted eight days and culminated in a finding announced on February 12,1993 , that it was in the child's best interests for her to remain with the DeBoers. ${ }^{24}$

The Michigan circuit court was thus persuaded to use the UCCJA in a manner contrary to its intended purpose: to prevent the legal uncertainty, and consequent instability in a child's life, that results from permitting contestants to start over in a second state after they have lost in the first. Apparently, the court accepted the argument later put forward by the DeBoers in the Michigan Supreme Court that "when the Iowa Supreme Court affirmed the judgment awarding custody to the natural father on September 23, 1992, and thereafter denied the DeBoers' request for rehearing, that made the decree final, and therefore modifiable."25 This type of incoherent argument is the result of trying to apply the terms of the UCCJA, designed to deal with the problems of modifiable custody orders, to a final judgment denying an adoption. As the Michigan Supreme Court subsequently observed,

[T] here is substantial doubt whether the Iowa decision is the kind of "custody order" that is modifiable at all. When we speak of modifying custody orders, we are ordinarily talking about the typical case of a contest between natural parents. Such orders are at least theoretically perpetually modifiable. Where circumstances change, modification can be made in the child's best interests, because the biological parents have an inherent right to care, custody, and control of the child. That rationale, however, does not apply in a case such as this involving an adoption petition. The decision not to terminate Daniel Schmidt's rights and to dismiss the adoption petition put an end to the proceeding, just as would have been the case had the Iowa courts terminated Schmidt's rights and finalized the adoption. To say that the or-

22. Id. at 653,656 . Schmidt's Michigan attorney did not contest the applicability of the UCCJA, probably because the Michigan version of the Act at that time included adoption proceedings within the statutory definition of a "custody proceeding." See Mich. CoMp. Laws ANN. \$ 600.652(c) (West 1981); cf. Mich. CoMp. LAws ANN. § 600.652(c) (West Supp. 1995) (reflecting deletion by Pub. Act 1982 , no. $66, \S 1$, of "adoption" from list of proceedings included in term "custody proceeding"). She did, however, challenge the DeBoers' standing to raise the custody issue. In re Clausen, 501 N.W.2d at $195-96$.

23. In re Clausen, 502 N.W.2d at 656; see U.S. CoNST. art. IV, § 1 ; see generally William L. Reynolds, The Iron Law of Full Faith and Credit, 53 MD. L. REv. 412 (1994) (exploring the basic rule of sister-state enforcement of judgments and the limited exceptions thereto).

24. In re Clausen, 502 N.W.2d at 653 n.9.

25. Id. at 657 . 
der in the instant case is modifiable would have the effect of destabilizing finalized adoptions as well as other final orders. ${ }^{26}$

The Michigan Supreme Court thus reached the same result as the Iowa Supreme Court, and, indeed, as the Illinois Supreme Court in Baby Richard's case. The latter two courts correctly concluded that once an adoption has been denied on the basis that the nonconsenting birth parent is a fit person to have custody, that parent has the right to his or her child's custody without having to undergo a "best interests" hearing. ${ }^{27}$ Justice Stevens, denying a stay of the motion for transfer in Baby Jessica's case, agreed: "Neither Iowa law, Michigan law, nor federal law authorizes unrelated persons to retain custody of a child whose natural parents have not been found to be unfit simply because they may be better able to provide for her future and her education."28

Like Justice Stevens, the state supreme courts came to the right conclusion. By the time the courts got it right, however, the danger of psychological damage to the children had already occurred. On the date the children were returned to their birth parents, Baby Jessica was two-and-one-half years old, and Baby Richard was four. The two cases could and should have been decided more quickly and more simply. The Illinois Marriage and Dissolution of Marriage Act, the UCCJA, and the $\mathrm{PKPA}^{29}$ had no place in the determination of custody in the cases of Baby Jessica and Baby Richard. The cases were commenced, and should have been concluded, under the respective adoption statutes of lowa and Illinois. ${ }^{30}$ The mothers relinquished their children under those provisions, the prospective adoptive parents filed their petitions for adoption in accordance with those provisions, the proceedings to terminate the parental rights of the biological fathers were undertaken pursuant to those provisions, and, when the fathers were found to be fit, the adoption petitions were denied according to those provisions. The question to be decided by the respective courts in both cases was limited to a simple inquiry: Was a father, who had not consented to the adoption of his child, unfit to serve as that child's parent? Once that question had been decided in the negative-as it was in both cases-no further appropriate legal avenues remained available to the prospective adoptive parents.

26. Id. at 657 n.22.

27. In re B.G.C., 496 N.W.2d 239, 245 (Iowa 1992); In re Kirchner, 649 N.E.2d 324, 330-32 (111.), cert. denied, 115 S. Ct. 2599, and cert. denied, 115 S. Ct. 2600 (1995).

28. DeBoer by Darrow v. DeBoer, 114 S. Ct. 1, 2 (1993).

29. In Baby Jessica's case, the Michigan Supreme Court held that the PKPA required it to enforce the lowa decision. In re Clausen, 502 N.W.2d at 658-59. The court thus reached the right result, but for the wrong reason. The lowa judgment denying the adoption was a final judgment. The Full Faith and Credit Clause, standing alone, required that Michigan enforce the Iowa judgment.

30. See lowa Code ANN. ch. 600 (West 1981 \& Supp. I995); 750 ILl. Comp. Stat. AnN. 50 (West 1993 \& Supp. 1995). 
Both cases began as, and should have remained, single-state adoption cases. That is, Baby Jessica's case should have been decided entirely within Iowa, just as Baby Richard's was decided within Illinois. As Baby Richard's four-year ordeal demonstrates, however, eliminating "interstate" complications would not in itself have solved all the problems in Baby Jessica's case. The fundamental problem, in each case, is that an adoption proceeding was forced into the mold of a "child custody proceeding" as that term is understood in marital dissolution cases. Neither case was, nor should have been permitted to become-on either the intrastate or interstate level-anything but an adoption case.

The cases of Baby Jessica and Baby Richard stimulated massive public outcry against adoption laws and court procedures that seemingly disregarded the best interests of children im order to uphold the legal rights of birth parents-in particular, of biological fathers. The Time magazine story that accompanied Baby Jessica's cover picture pointed out that in the search for a villain, "[t]he one target everyone can hate with equal passion is the legal system that placed two families and a child on the rack for $21 / 2$ years." ${ }^{\prime 31}$ Baby Richard's case was taken up by a newspaper columnist whose scathing attacks on the Illinois Supreme Court were pointedly described, in a remarkable supplementary opinion by a justice of that court, as "acts of journalistic terrorism." ${ }^{32}$

Like the popular criticism, the academic discussion of the two cases has found much to fault. ${ }^{33}$ That discussion, however, has largely ignored one important distinction between the cases. Baby Richard's case remained in its entirety a single-state case. By contrast, because Baby Jessica's case touched two states-Iowa, where she was born, where the adoption proceedings were filed, and where her birth parents lived; and Michigan, where the DeBoers lived and where she resided with them for two-and-one-half years - her case was treated, in its latter stages, as a conflict of laws case. While observers may reasonably differ concerning whether either case reached the correct result as a matter of substantive adoption law and policy, the Michigan Supreme Court's controversial decision to respect the Iowa judgment and to order Baby Jessica re-

31. Gibbs, supra note 1 , at 47.

32. In re Doe, 638 N.E.2d 18I, 189 (Ill.) (supplemental op. on denial of reh'g) (McMorrow, J., concurring), cert. denied, 115 S. Ct. 499 (1994).

33. See, e.g., Kirsten Korn, Comment, The Struggle for the Child: Preserving the Family in Adoption Disputes Between Biological Parents and Third Parties, 72 N.C. L. Rev. 1279 (1994). But see Lynn Kirsch, Note, Unwed Fathers and Their Newborn Children Placed for Adoption: Protecting the Rights of Both in Custody Disputes, 36 ARIz. L. REv. 1011 (1994) (proposing uniform system for resolving adoption disputes in order to forestall forum shopping and other tactics leading to inconsistency and delay). 
turned to her birth parents was correct as a matter of conflicts law. It was correct, however, for the wrong reasons.

Simply put, Baby Jessica not only had to contend with the mischaracterization of an adoption case as a "custody proceeding," but also had to confront-as Baby Richard did not-the misapplication to adoption of specific interstate jurisdictional statutes. This Article now turns to explore the circumstances that led the participants and judges who handled the conflicts aspects of Baby Jessica's case to misinterpret the UCCJA and the PKPA, thus building on the errors of earlier precedents in a way that requires exposure, examination, and rejection by future courts.

\section{II \\ MisapPLICATION OF THE UCCJA AND PKPA to INTERSTATE AdOPTION CASES}

\section{A. The Purpose of the Acts: To Resolve Interstate Child Custody Disputes in Divorce Cases}

The UCCJA was designed to solve one, and only one, problem: the lack of stability in custody awards following the breakdown of a family through divorce or separation. Although the text of the Act speaks in general terms of "child custody," the opening paragraph of the Commissioners' Prefatory Note ${ }^{35}$ describes a typical struggle over children carried on by divorcing parents and a dispute between grandparents and separated parents over care of the children. In her initial article explaining the Act, Professor Brigitte M. Bodenheimer, the Reporter for the UCCJA, identified the plight of "children of divorce" and other children who "live under court-determined custody arrangements" as the central problem which the Act sought to resolve. ${ }^{36}$

34. E.g., UCCJA § 1(a), 9 U.L.A. pt. 1, at 123-24 (1988): "The general purposes of this Act are to: (1) avoid jurisdictional competition and conflict with courts of other states in matters of child custody which have in the past resulted in the shifting of children from state to state with harmful effects on their well-being....".

35. 9 U.L.A. pt. 1, at 116:

There is growing public concern over the fact that thousands of children are shifted from state to state and from one family to another every year while their parents or other persons battle over their custody in the courts of several states. Children of separated parents may live with their mother, for example, but one day the father snatches them and brings them to another state where he petitions a court to award him custody while the mother starts custody proceedings in her state; or in the case of illness of the mother the children may be cared for by grandparents in a third state, and all three parties may fight over the right to keep the children in several states.

36. Brigitte M. Bodenheimer, The Uniform Child Custody Jurisdiction Act: A Legislative Remedy for Children Caught in the Conflict of Laws, 22 VAND. L. Rev. 1207, 1208 (1969); see also Anne B. Goldstein, The Tragedy of the Interstate Child: A Critical Reexamination of the Uniform Child Custody Jurisdiction Act and the Parental Kidnaping Prevention Act, 25 U.C. DAVIS L. REv. 845, 868-85 (1992) (describing the background of the UCCJA). 
The UCCJA was drafted to address two principal causes of instability in custody orders arising from cases of family breakdown. First, overlapping jurisdiction among several states to decide the custody issue encouraged forum shopping. Second, any order issued lacked finality because prevailing state law provided that custody orders generally are not final, but are subject to modification during the child's minority. As Professor Bodenheimer noted in explaining the need for the UCCJA, "[t]he cardinal rule of custody law is that the court must be governed above all by a concern for the best interests or welfare of the child.... [T]he notion that non-finality, fluidity, and modifiability of custody decrees are necessary in the interest of the child [has become] generally accepted." ${ }^{\prime 37}$ The United States Supreme Court, in a series of cases, had continued this "unfortunate assumption," 38 holding that a custody decree modifiable in the state where it was rendered could also be modified by the courts of other states. ${ }^{39}$ Thus, a parent dissatisfied with an adverse custody decision could remove the child to another state and start over again to try to obtain a more favorable result.

The primary goal of the UCCJA was to overcome this instability in child custody decisions by identifying one state as the state having jurisdiction to issue an initial custody decree, and then requiring that the initial custody determination be recognized and enforced by any court where modification might later be sought. ${ }^{40}$ When experience with the UCCJA made clear that this objective had not been attained, ${ }^{41}$ Congress enacted the PKPA in part to clarify the order of priority among states for assuming jurisdiction to enter the initial decree, and to ensure that only a decree rendered under the UCCJA in conformity with that priority would be entitled to full faith and credit in other states. ${ }^{42}$

Neither the UCCJA nor the PKPA was designed to apply to interstate adoption cases. The word "adoption" does not appear in the text

37. Bodenheimer, supra note 36 , at 1209-10.

38. Id. at 1210.

39. See, e.g., Kovacs v. Brewer, 356 U.S. 604, 607 (1958); New York ex rel. Halvey v. Halvey, 330 U.S. 610, 615 (1947); see generally Bodenheimer, supra note 36, at 1210-13 (describing the Supreme Court's rulings on state modifications of custody decrees).

40. See UCCJA § 3, 9 U.L.A. pt. 1, at 143; UCCJA § 13, 9 U.L.A. pt. 1, at 276; UCCJA § 14, 9 U.L.A. pt. 1, at 292 (1988); see also Bodenheimer, supra note 36, at 1218-19.

41. See Brigitte M. Bodenheimer, Progress Under the Uniform Child Custody Jurisdiction Act and Remaining Problems: Punitive Decrees, Joint Custody, and Excessive Modifications, 65 CALIF. L. Rev. 978, 1012-14 (1977) (discussing courts' frequent modifications of their own custody determinations, and the responses of other states' courts); Russell M. Coombs, Interstate Child Custody: Jurisdiction, Recognition, and Enforcement, 66 MINN. L. Rev. 711, 735 (1982) (discussing confusion under the UCCJA regarding initial jurisdiction).

42. See, e.g., Roger M. Baron, Federal Preemption in the Resolution of Child Custody Jurisdiction Disputes, 45 ARK. L. REv. 885, $891-92$ (1993); Coombs, supra note 41, at 735, 765. It has been argued that the PKPA was no more successful than the UCCJA in achieving this goal. See Goldstein, supra note 36 , at 921-33. 
of either Act, nor, contrary to a mistaken reading of one of her articles, did Professor Bodenheimer ever suggest that such an application was intended. ${ }^{43}$ The reason is simple: unlike child custody determinations, court orders decreeing or denying adoptions are, under state law, final judgments not subject to modification. ${ }^{44}$ The Full Faith and Credit Clause of the United States Constitution requires that such a judgment be accorded the same finality and enforced in sister states. While jurisdiction to determine a petition for adoption may exist concurrently in several states, the decree of the first state to reach judgment is not, unlike

43. In holding that the UCCJA applies to adoption proceedings, the Supreme Court of Georgia relied both on the "language and purpose" of the Act, and on its mistaken assumption that "Professor Bodenheimer, the drafter and reporter for the UCCJA, has written that the UCCJA should be applied to adoption proceedings." Gainey v. Olivo, 373 S.E.2d 4, 6 (Ga. 1988). The Court's reference was to Brigitte M. Bodenheimer \& Janet Neeley-Kvarme, Jurisdiction Over Child Custody and Adoption After Shaffer and Kulko, 12 U.C. DAv1s L. REv. 229 (1979). In that article, the authors survey a broad range of child custody proceedings to determine the impact on those proceedings of the Supreme Court's decisions requiring personal jurisdiction over defendants in both derivative shareholder suits and child support proceedings. In the section of their article setting out the scope of their analysis, the authors state: "Child custody proceedings in the broad sense used in this article include divorce custody disputes, guardianship, neglect and abuse cases, adoptions, and actions to terminate parental rights." Id. at 232 . The Gainey court apparently read this sentence together with the comment to section 2 of the UCCJA, which states that the term "'custody proceeding' is to be understood in a broad sense," 9 U.L.A. pt. 1, at 134, and concluded that Professor Bodenheimer intended that the term "custody proceeding" in section $2(3)$ should include adoption proceedings. Gainey, 373 S.E.2d at 6 . This interpretation, however, misreads both the comment to section 2 and the U.C. Davis Law Review article. The comment goes on to say, in the next sentence, that "[t]he term covers habeas corpus actions, guardianship petitions, and other proceedings available under general state law to determine custody." 9 U.L.A. pt. 1, at 134. Adoption proceedings are not included in the list. Bodenheimer and Neeley-Kvarme devote Part V of their article to a discussion of "Particularized Rules of Jurisdiction in Child Custody and Related Proceedings." Bodenheimer \& Neeley-Kvarme, supra, at 241-48. The subsections of Part V include several different types of custody proceedings: "Termination of Parental Rights," "Adoptions," "Divorce Custody," "Guardianship," and "Neglect and Abuse." The authors refer to the UCCJA only in their discussions headed "Divorce Custody" and "Guardianship." The UCCJA is not mentioned in the subsection entitled "Adoptions." See id. at 243-44. Moreover, "Divorce Custody," id. at 244-47, contains a description of the UCCJA's origins in which the authors note that the Restatement (Second) of Conflict of Laws $\$ \S 69,79$ (1971) had incorporated Justice Traynor's threefold approach to child custody jurisdiction announced in Sampsell v. Superior Court, 197 P.2d 739, 750 (Cal. 1948), which recognized concurrent jurisdiction in the state of the child's domicile, the state where the child was present, and the state which has personal jurisdiction over the contesting parties. In announcing this multiple jurisdiction approach, Justice Traynor had admonished courts to use restraint in exercising jurisdiction in order to avoid harm to children. Id. This warning was ineffective. As the authors note, "there has been a proliferation of jurisdiction, often resulting in conflicting custody decrees in several states. Child-snatching ... became increasingly common in the 1950's and 1960's. For these reasons the Uniform Child Custody Jurisdiction Act was developed, which substantially restricts the jurisdictional bases of the Restatement." Bodenheimer \& Neeley-Kvarme, supra, at 245 (footnotes omitted) (emphasis added).

44. 1 Adoption LAW AND PRACTICE § 1.01[2][e] (Joan H. Hollinger ed., 1994): "A fifth characteristic is that adoptive relationships are permanent.... In the absence of fraud or some other fundamental irregularity, adoption decrees are final and irrevocable, and affect future generations as well as the present one." 
a child custody decree, open to modification elsewhere. The UCCJA and the PKPA are superfluous in adoption cases.

\section{B. The Structure of the Acts: Incongruity with Adoption Proceedings}

1. Initial Jurisdiction: Typically There Is No "Home State"

The structure of the UCCJA was designed to fit the fact pattern of the typical interstate child custody dispute in a divorce case. It does not fit the fact pattern of the typical interstate adoption case. In her first article describing the structure of the UCCJA, Professor Bodenheimer wrote:

The basic scheme of the Act is simple. First, one court in the country assumes full responsibility for custody of a particular child. Second, for this purpose a court is selected which has access to as much relevant information about the child and family in the state as possible. Third, other essential evidence, which is inevitably out-of-state in the case of an interstate child, is channelled into the first court which might be called the "custody court." Fourth, other states abide by the decision of the custody court and enforce it in their territory, if necessary. Fifth, adjustments in visitation and other ancillary provisions of the decree, and custody changes, if any, are as a rule made by the original custody court. Sixth, if the child and his family no longer have appreciable ties with the state of the original court, a new custody court is selected to take the place of the original one for purposes of adjustments and modifications, and pertinent information is channelled from the prior to the subsequent custody court.

This scheme is carried out by the major provisions of the Act. Section 3 provides that jurisdiction in custody cases is normally limited to the courts of the state which is the child's home state or in which there are other strong contacts with the child and his family. Sections 6 and 7 assure that any possible jurisdictional conflict between the courts of several states are resolved by the priority-in-time or the inconvenient forum principle, aided by direct interstate judicial communications. Sections 19-22 instruct courts to assist each other in gathering out-ofstate evidence by holding hearings on behalf of a custody court in another state, by forwarding court records, and in other ways. Sections 13 and 15 provide that a custody decree rendered in accordance with the jurisdictional standards of the Act be accorded recognition and direct enforcement in any other state. Under section 14 the power to modify a custody decree remains exclusively in the court which made the prior decree so long as that court satisfies the jurisdictional requirements of the Act. 
Every section of the Act is to be applied in light of its basic purposes, as expressed in section 1, to discourage continuing controversies over child custody in the interest of stability of home environment for the child, to deter child abductions and similar practices employed to obtain custody awards, and to promote mutual interstate judicial assistance in custody cases. ${ }^{45}$

This description of the Act's structure is redolent with the notion that the child has been living with both parents in a single state (the "home state") and that the family has separated, with one parent taking the child to another state. One of the major purposes of the Act, drafted as it was in the heyday of migratory divorces, was to make clear that a divorce court chosen by a leave-taking parent, or even by both parents, usually to obtain a more lenient ground for divorce, lacked jurisdiction over the question of child custody. ${ }^{46}$ Thus, under the UCCJA, if a parent eager to remarry as quickly as possible left the marital home to take the well-trodden "road to Reno," 47 Nevada might obtain jurisdiction to dissolve the marriage, but even if both spouses appeared in the divorce proceedings, Nevada would be unable to award custody of the child.

As originally drafted, the UCCJA permitted overlapping jurisdiction among states: the child's "home state" and any other state with which the child and his parents, or the child and at least one contestant, has a "significant connection." 48 The Act defined the "home state" as

the state in which the child immediately preceding the time involved lived with his parents, a parent, or a person acting as parent, for at least 6 consecutive months, and in the case of a child less than 6 months old the state in which the child lived from birth with any of the persons mentioned. ${ }^{49}$

After one of these states had assumed jurisdiction over the custody matter, and had entered the first custody decree affecting a child (an

45. Bodenheimer, supra note 36 , at 1218-19.

46. See UCCJA $\$ 3 \mathrm{cmt}$, 9 U.L.A. pt. 1, at 145:

Paragraph (2) of subsection (a) is supplemented by subsection (b) which is designed to discourage unilateral removal of children to other states and to guard generally against too liberal an interpretation of paragraph (2). Short-term presence in the state is not enough even though there may be an intent to stay longer, perhaps an intent to establish a technical "domicile" for divorce or other purposes.

... The submission of the parties to a forum, perhaps for purposes of divorce, is not sufficient without additional factors establishing closer ties with the state. Divorce jurisdiction does not necessarily include custody jurisdiction.

Since the Act's drafting, the acceptance of no-fault divorce in all 50 states has made migratory divorce a less pressing issue.

47. See nelson M. Blake, The Road to Reno: A History of Divorce in the United STATES (1962).

48. UCCJA § 3(a)(2), 9 U.L.A. pt. 1, at 143.

49. UCCJA § 2(5), 9 U.L.A. pt. 1, at 133; see UCCJA § 3(a)(1), 9 U.L.A. pt. 1, at 143. 
"initial decree" 50 ), that state retained jurisdiction until it lost jurisdiction or declined to act. . $^{\text {si }}$

When the PKPA was enacted in 1980 to put the force of the Full Faith and Credit Clause behind the UCCJA, it made one change that rendered the UCCJA more effective in child custody proceedings, but even less suitable for adoption cases. The PKPA, by providing that a state may not assert "significant connection" jurisdiction unless "it appears that no other State would have jurisdiction," ${ }^{52}$ gave priority to the "home state" over any state with "significant connections." This change, which provided greater stability in divorce custody proceedings by reducing conflict between states, has the opposite effect if applied to the case of an interstate adoption by strangers. The reason is that there is no "home state" in the vast majority of interstate stranger adoption cases, where the child is relinquished shortly after birth and taken to live in a different state with prospective adoptive parents who have had no prior contact with the child. If one of the birth parents has not consented to the relinquishment, or if one or both of them seek to withdraw consent, the courts of two states may become involved. Without the clarity provided by a primary "home state," courts relying on the PKPA are left to choose between states with "significant connection" jurisdiction, thus undermining the stability that the Act sought to create.

The problems created by the lack of a "home state" in attempting to apply the UCCJA and the PKPA to interstate stranger adoption cases became obvious early on. In the case known variously as Rogers $v$. Platt $^{54}$ and In re B.B.R., "B5 "Baby Boy Rogers" was born to Marita Belle Rogers in California on June 14,1985. During the pregnancy, Rogers had expressed to her obstetrician, Dr. Bruce Bob, her wish to place the baby for adoption. Dr. Bob assisted the mother in placing Baby Boy Rogers with Alan and Kathy Platt, who lived in Washington, D.C. When the Platts arrived in California on June 15, the mother signed a temporary release form allowing them to remove Baby Boy Rogers from the hospital. ${ }^{56}$ The Platts returned to the District of Columbia with the baby

50. UCCJA \& 2(5), 9 U.L.A. pt. 1, at 133.

51. UCCJA \& 14(a), 9 U.L.A. pt. 1, at 292.

52. 28 U.S.C. $\& 1738 \mathrm{~A}(\mathrm{c})(2)(\mathrm{B})(\mathrm{i})(1994)$.

53. See Coombs, supra note 41, at 778-80; Linda M. DeMelis, Note, Interstate Child Custody and the Parental Kidnapping Prevention Act: The Continuing Search for a National Standard, 45 Hastings L.J. 1329, 1336 (1994).

54. 245 Cal. Rptr. 532 (Ct. App. 1988). The statement of facts in the text is taken from id. at 533-34.

55. 566 A.2d 1032 (D.C. 1989).

56. The form, entitled "Health Facility Release Report of Minor to Other Than Parent or Legal Guardian," contained the following scntence: "In releasing my child from hospital for the purpose of adoption planning, 1 retain all parental rights to his/her custody and control." Rogers, 245 Cal. Rptr. at 533-34. 
the following day. On June 18, Dr. Bob informed the Platts that Marita was having "second thoughts" about the adoption. ${ }^{57}$ Despite this and other indications that the mother wanted the baby back, the Platts did not return him.

In the legal proceedings that ensued, ${ }^{58}$ Marita Rogers filed a habeas corpus petition in California on November 21, 1985, while the Platts filed a petition for guardianship in the District of Columbia a day later, followed by a petition for adoption on February 18, 1986. Both lower courts applied the PKPA, and each held that its state was the "home state" under the Act.

Faced with conflicting determinations as to jurisdiction, the mother invoked the aid of the Federal District Court under the PKPA to decide whether California or the District of Columbia (which is treated as a state for purposes of the $\mathrm{PKPA}^{59}$ ) had jurisdiction to proceed. ${ }^{60}$ In the course of deciding that matter, the district court concluded that Baby Boy Rogers had no home state: "Because the child did not 'live from birth with' the plaintiff or defendants, the Court concludes no state is the 'home state' for determining PKPA jurisdiction." The district court then addressed the "next prioritized subsection of the Act," "significant connection" basis for jurisdiction. Not surprisingly, the court concluded that both California and the District had significant connections to the child and to each contestant. It went on to decide that California had a "much more significant" connection than the District, pointing to the mother's permanent residence, the child's birth, the Platts' refusal to return the child after the mother had revoked her permission for them to remove the child, and the fact that the mother had filed her habeas corpus proceeding one day prior to the time the Platts filed their petition for guardianship. ${ }^{63}$

After the district court's judgment had been reversed for lack of subject matter jurisdiction, ${ }^{64}$ the contestants resumed the struggle in their

57. Id. at 534 n.I.

58. The factual statements in this paragraph are taken from In re B.B.R., 566 A.2d at 1035 \& กn.5-6.

59. 28 U.S.C. $\S 1738 \mathrm{~A}(\mathrm{~b})(8)$.

60. Rogers v. Platt, 641 F. Supp. 381 (D.D.C. 1986), rev'd, 814 F.2d 683 (D.C. Cir. 1987).

61. Id. at 387 (quoting 28 U.S.C. $\$ 1738 \mathrm{~A}(\mathrm{~b})(4)$ )).

62. Id.

63. Id. at 387-88.

64. Rogers v. Platt, 814 F.2d 683, $695-96$ (D.C. Cir. 1987); see also Thompson v. Thompson, 484 U.S. 174 (1988) (holding that the PKPA does not confer subject matter jurisdiction on the federal courts). In response to the Baby Jessica case, the American Academy of Matrimonial Lawyers has proposed that Congress overrule Thompson by amending the PKPA to add at the end a new subsection (h) that would read as follows: "The district courts shall have jurisdiction of any action to determine, in the case of a dispute involving custody determinations of different states, whether such custody determinations were made consistently with the provisions of this section." Linda Lea M. Viken, Calling in the Feds: The Need for an Impartial Referee in Interstate Child Custody Disputes, 39 S.D. L 
respective locales. Eventually, appellate courts in both California ${ }^{65}$ and the District ${ }^{65}$ held that neither was the child's "home state"; remarkably, both courts agreed that California should exercise "significant connection" jurisdiction. When the Court of Appeals for the District of Columbia handed down its decision on November 2, 1989, Baby Boy Rogers was nearly four-and-one-half years old. His mother, Marita Rogers, having won her case, chose to permit him to remain with the Platts. ${ }^{67}$

Baby Boy Rogers lacked a "home state" because he had not lived "from birth" to the commencement of the proceedings with either his mother or the Platts, as required by both the UCCJA ${ }^{68}$ and the PKPA ${ }^{69}$ for children less than six months old. That two state lower court judges, in defiance of this specific language, nevertheless concluded that Baby Boy Rogers did have a "home state" in their respective jurisdictions is astonishing. Even more astonishing is the federal district court judge's candid statement that, if the PKPA had not offered the "significant connection" jurisdiction as an option, he, too, would have stretched the definition of "home state" to find that California fit this description." If courts will not respect the clear limits on jurisdiction imposed by the "home state" requirement, how can they be expected to apply the more flexible "significant connection" source of jurisdiction consistently? Yet Baby Boy Rogers's predicament is not unique among stranger adoption cases. Indeed, his case parallels that of Baby Jessica and many

Rev. 469, 475-76 \& n.79 (1994), (quoting H.R. 4188, 103d Cong., 2d Sess. (1994)). In rejecting a similar approach when the PKPA was enacted, Congress was, according to the Court in Thompson, persuaded by a letter written by then-Assistant Attorney General Patricia Wald to the Chair of the House Judiciary Committee in which she expressed opposition to the creation of a federal forum for resolving custody disputes. Thompson, 484 U.S. at 185 . The Justice Department opposed federal jurisdiction because it would "entangle the federal judiciary in domestic relations disputes with which they have little experience and which traditionally have been the province of the States." Id. Jurisdictional decisions are not easily separated from substantive matters, as a careful reading of the district court's opinion in Rogers should make clear.

65. Rogers v. Platt, 245 Cal. Rptr. 532, 539 (Ct. App. 1988).

66. In re B.B.R., 566 A.2d 1037, 1032 (D.C. 1989).

67. Letter from Glendalee Scully, counsel for Marita Rogers, to Herma Hill Kay (Jan. 10, 1996) (on file with author).

68. UCCJA \& 2(5), 9 U.L.A. pt. 1, at 133.

69. 28 U.S.C. $\S 1738$ A(b)(4).

70. Rogers v. Platt, 641 F. Supp. 381, 386 (D.D.C. 1986), rev'd, 814 F.2d 683 (D.C. Cir. 1987): "If 'home State' analysis was the only basis for determining jurisdiction under the PKPA, the Court would have to conclude the 'home State' was California because that is where the child 'lived from birth." The court could have reached that conclusion only by ignoring the requirement that the child must have lived in the home state "from birth" immediately preceding the time when proceedings were commenced. Unfortunately, this court is not alone in its willingness to contort the home state provision of the PKPA in order to reach results that "defy common sense." See DeMelis, supra note 53, at 1343; see generally Goldstein, supra note 36 , at $885-915,922-33$ (discussing the "crucial indeterminacies" of the UCCJA and the PKPA). 
others. $^{71}$ The continued application of the PKPA and the UCCJA to such cases will not produce uniformity, but instead will create further conflict between birth parents and prospective adoptive parents, both understandably intent on exclusive possession of the child. ${ }^{72}$

\section{Achieving Finality: Adoption Orders Are Not Modifiable}

The UCCJA recognizes the possibility that modification of the initial custody decree may be sought, either in the custody state or in another state. ${ }^{73}$ Once again, this recognition bespeaks the drafters' focus on divorce custody proceedings, not on adoption proceedings. As noted earlier, ${ }^{74}$ custody decisions affecting minor children may be modified. A court order granting or denying an adoption, by contrast, is not subject to modification. Rather, it is a final judgment. Therefore, Section 14 of the UCCJA, which is designed to deter a second state from modifying a custody decree as long as the rendering court continues to exercise jurisdiction substantially in accordance with the Act, is unnecessary to protect final judgments of adoption.

71. In Baby Jessica's case, the Michigan Supreme Court engaged in a complex and questionable analysis designed to make the case fit the contours of the PKPA. Thus, the court determined that Iowa had jurisdiction over the termination and adoption proceedings because lowa was Baby Jessica's "home state." In re Clausen, 502 N.W.2d 649, 658 (Mich.), stay denied sub nom. DeBoer by Darrow v. DeBoer, 114 S. Ct. 1 (Stevens, J.), and stay denied, 114 S. Ct. 11 (1993). This claim drew strong criticism from the dissent. Id. at 672-75 (Levin, J., dissenting). The dissent, however, was equally incorrect in its assertion that Michigan was Jessica's "home state." See id. Actually, Baby Jessica had no "home state" as that term is used in the PKPA and the UCCJA. See supra text accompanying notes 68-69. The conflicting and mutually inaccurate assertions that she did are the product of the court's unnecessary and mistaken reliance on the PKPA.

72. For a recent illustration of this point, see J.D.S. v. Franks, 893 P.2d 732 (Ariz. 1995), discussed infra in text accompanying notes 174-184.

Consider as well In re Adoption of Child by T.W.C. and P.C., 636 A.2d 1083 (N.J. Super. Ct. App. Div. 1994), a case in which a New York birth mother first relinquished her newborn son for private placement with a New Jersey couple, then revoked her consent to the adoption two-and-ahalf months later. In applying the UCCJA and PKPA to determine whether New Jersey, where the adoption proceeding had been commenced, had jurisdiction, the New Jersey court correctly held that neither New York nor New Jersey could qualify as the "home state." The court suggested that this fact did not create any problem, because of the availability of the "significant connection" basis for jurisdiction under the PKPA. Nor was the court troubled by the realization that both New Jersey and New York might qualify as having a significant connection with the case:

[N] either the UCCJA nor the PKPA requires that one state's "substantial contacts" be weighed against another state's "substantial contacts" in order to entrust a single state with jurisdiction. More than one state may have connections sufficient to support original jurisdiction; the PKPA specifically contemplates that possibility, prohibiting a state from exercising jurisdiction where another state "is exercising jurisdiction consistently with the provisions [of the PKPA]."

Id. at 1089 (quoting 28 U.S.C. $\$ 1738 \mathrm{~A}(\mathrm{~g})$ ) (citation omitted) (alteration in original). Under this mistaken interpretation, the PKPA will routinely lose its power to identify a single state with jurisdictional primacy if the statute continues to be misapplied in adoption proceedings. A multiplicity of proceedings is exactly what the PKPA was designed to avoid.

73. UCCJA § 14, 9 U.L.A. pt. 1, at 292.

74. See supra text accompanying note 37 . 
Any remaining doubt as to the inapplicability of the UCCJA to adoption proceedings is dispelled by reference to the words of the Act's Reporter. As practice developed under the UCCJA, it became clear that many states either did not understand or did not respect the limitations imposed by Section 14. In her last article on the subject, Professor Bodenheimer warned that "[s]ome courts have overlooked, disregarded, or misread the key provision of Section 14 or have misinterpreted its meaning." 75 She continued,

[T] here have been some misunderstandings surrounding the "home state" concept. It has been erroneously assumed, for example, that after a child lives in a state for six months on an extended visit or a joint custody arrangement, that state acquires concurrent jurisdiction. This is not the law. The original court has continuing jurisdiction and that jurisdiction is exclusive. In appropriate cases, this court will decline the exercise of its jurisdiction and may relinquish jurisdiction to the new home state, especially if the child has lived there for several years. Unless declined, jurisdiction remains in one single court. This is the Act's major device to prevent conflicts of modification jurisdiction. ${ }^{76}$

Bodenheimer's warning is appropriate only in the context of judicial orders that are subject to modification. It is superfluous in the context of final judgments, such as those entered in adoption proceedings. One may be certain that Professor Bodenheimer was well aware of the difference.

\section{Early Adoption Cases Misinterpreted the UCCJA}

Unfortunately, courts lacking Professor Bodenheimer's expertise have persistently misapplied the UCCJA since the earliest days of its enactment. Professor Bernadette W. Hartfield's analysis of the early cases that mistakenly applied the UCCJA to adoption proceedings reveals two distinct types of cases. ${ }^{77}$ In the first type, which includes some of the earliest cases, courts simply applied the UCCJA without discussion. ${ }^{78}$ In

75. Brigitte M. Bodenheimer, Interstate Custody: Initial Jurisdiction and Continuing Jurisdiction Under the UCCJA, 14 FAM. L.Q. 203, 216 (1981). Professor Bodenheimer died on January 7, 1981, as her article was going to press. Id. at vii.

76. Id. at 226-27.

77. Bernadette W. Hartfield, The Uniform Child Custody Jurisdiction Act and the Problem of Jurisdiction in Interstate Adoption: An Easy Fix?, 43 OKLA. L. REv. 621 (1990).

78. Id. at $639-43$ (discussing In re Adoption of K.C.P., 432 So. $2 d 620$ (Fla. Dist. Ct. App. 1983); In re Adoption of Baby Boy IV., 701 S.W.2d 534 (Mo. Ct. App. 1985); Noga v. Noga, 443 N.E.2d 1142 (1ll. App. Ct. 1982); and E.E.B. v. D.A., 446 A.2d 871 (N.J. 1982), cert. denied, 459 U.S. 1210 (1983)). 
the second type of case, courts erroneously construed the term "custody proceeding" to include adoption proceedings. ${ }^{79}$

One case of the latter type has been particularly influential. Gainey v. Olivo $^{80}$ involved a child born in New York to an unmarried woman, Stephanie Flagg, on December 12, 1985. The mother relinquished the child to a private adoption agency for placement; the father, Manuel Olivo, did not consent and filed suit in New York for paternity and custody on March 26, 1986. The next day, the agency delivered the child to an attorney who transferred him to Georgia, where he was placed for adoption with the Gaineys. The Gaineys commenced adoption proceedings in Georgia on August 4. On September 18, the New York court declared Olivo to be the father. The court reserved jurisdiction over the matter of custody of the child, and enjoined the adoption pending its decision of that matter. The New York court's order was served on the parties in the Georgia proceedings. Nonetheless, on February 5, 1987, the Georgia trial court terminated the father's parental rights and ordered the adoption. On appeal, the father argued that New York retained sole jurisdiction. He invoked the UCCJA and the PKPA in support of his claim. The Georgia Court of Appeals, overruling its earlier contrary decision in In re C.C.B. ${ }^{81}$ held that the UCCJA's language and purpose "simply does not apply to adoption proceedings."

Although the Georgia Supreme Court affirmed the judgment of the court of appeals, it nonetheless held that the UCCJA applied based on a broad construction of the term "custody proceeding." nate interpretation resulted not only from the court's misreading of the language and purpose of the Act, but also from its mistaken reading of one sentence in an article co-authored by Professor Bodenheimer. The court apparently took this sentence to suggest that "the UCCJA should be applied to adoption proceedings." 84 Read in the context of the en-

79. Id. at $644-49$ (discussing Souza v. Superior Court, 238 Cal. Rptr. 892 (Ct. App. 1987); In re Adoption of B.E.W.G., 549 A.2d 1286 (Pa. Super. Ct. 1988); Gainey v. Olivo, 373 S.E.2d 4 (Ga. 1988); and Foster v. Stein, 454 N.W.2d 244 (Mich. Ct. App. 1990)).

80. 373 S.E.2d 4 (Ga. 1988). On its facts, Gainey properly held that Georgia should have deferred to proceedings instituted by the putative father in New York, which had already determined that he was the child's legal father and reserved the custody issue. See id. at 5, 7. The reason for the deferral, however, should have been that the father's status had been determined by the New York court and was entitled to recognition in Georgia, not that the UCCJA applied. See id. at 6-7.

81. 296 S.E.2d 198 (Ga. Ct. App. 1982).

82. Olivo v. Gainey, 364 S.E.2d 279, 280 (Ga. Ct. App. 1987), aff'd on other grounds, 373 S.E.2d 4 (Ga. 1988).

83. Gainey, 373 S.E.2d at 6-7. The Georgia Supreme Court concluded that although the UCCJA applied, the Georgia trial court should have deferred to the New York court. Id, at 7.

84. Id. at 6 (citing Bodenheimer \& Neeley-Kvarme, supra note 43). Bodenheimer and NeeleyKvarme, however, clarified that "[c]hild custody proceedings in the broad sense used in this article include divorce custody disputes, guardianship, neglect and abuse cases, adoptions, and actions to terminate parental rights." Bodenheimer \& Neeley-Kvarme, supra note 43 , at 232 (emphasis added). 
tire article, however, the sentence does not support the court's interpretation. Rather than describing the coverage of the UCCJA, the sentence merely sets out the range of topics to be discussed in the article. ${ }^{85}$ Neither this sentence nor the article as a whole supports the Gainey court's interpretation of the UCCJA.

Moreover, Gainey erroneously cites two cases as precedent for extending the UCCJA to adoption cases. Read narrowly, neither case explicitly so holds. In Souza v. Superior Court, ${ }^{86}$ Jeffrey and Jessica Souza were divorced in Hawaii on March 5, 1982. Jessica was pregnant at the time; the Hawaii court retained jurisdiction over the custody proceeding. The parties' daughter, Janel, was born in Hawaii on June 15; her parents agreed that Jessica would have custody while Jeffrey would support Janel and would have visitation rights. The Hawaii court approved this agreement. On May 11, 1983, the mother and child moved to California. The father, who continued to live in Hawaii, lost contact with his daughter and former wife after their departure. ${ }^{87}$ In 1984, Jessica married Keith Bristow; they continued to live in California with Janel.

On November 26, 1986, Keith commenced a proceeding in California for a stepparent adoption of Janel. Notified of this petition, Jeffrey responded by filing a motion for visitation with the Hawaii court on March 4, 1987. The Hawaii court, declaring itself to be exercising jurisdiction substantially in conformity with the UCCJA, granted the father's motion. The stepfather urged that the California court disregard the order on the ground that the UCCJA was not applicable to adoption proceedings. ${ }^{88}$ The Souza court rejected this argument and held itself bound by the Act to defer to the jurisdiction of the Hawaii court. ${ }^{89}$ In reaching this conclusion, the court was clearly correct: because Hawaii had entered the initial custody decree and had continued to act in conformity with the UCCJA, the California courts should not have assumed jurisdiction to modify the Hawaii custody order in any way. Regardless of whether the request was for a stepparent adoption or simply for an order changing the father's visitation rights, Hawaii retained exclusive jurisdiction over Janel's custody. The California court properly deferred to the courts of Hawaii to determine whether Jeffrey had abandoned his daughter.

Unfortunately, the California court went on to state expansively that the stepfather's "argument" that the UCCJA does not regulate adop-

85. See supra note 43 for a discussion of the internal evidence in the Bodenheimer and NeeleyKvarme article that contradicts the court's interpretation.

86. 238 Cal. Rptr. 892 (Ct. App. 1987).

87. The parties disagreed whether Jeffrey voluntarily failed to maintain contact with Jessica and Janel after their departure, or whether he was not informed of their whereabouts. Id. at 893 .

88. Id. at 893-94.

89. Id. at 896 . 
tions "is clearly wrong." That assertion was unnecessary and should not be regarded as part of the holding of the case. Read narrowly, as the Gainey court should have read it, Souza stands solely for the proposition that the UCCJA requires deference to the initial forum in a child custody suit arising from divorce. Anything else is dicta.

The second case on which Gainey improperly relied, E.E.B. v. $D . A .,^{91}$ did not involve an adoption proceeding at all. ${ }^{92}$ The court in E.E.B. did, however, rely on both the UCCJA and the PKPA in its refusal to recognize a prior Ohio judgment ${ }^{93}$ granting a birth mother's petition for a writ of habeas corpus to recover custody of her daughter. ${ }^{94}$ In addition to its mention in Gainey, E.E.B. was cited prominently by the dissent in Baby Jessica's case. ${ }^{95}$ For that reason, the case warrants extended examination.

Doris Angle, an unmarried woman, gave birth to a baby girl in Ohio on October 13, 1978.96 Three days later, she and the father signed a "permanent surrender" relinquishing the child to the Holmes County Welfare Department for adoption. The welfare department placed the baby for adoption with an Ohio couple, the Bowens, three days after the surrender was signed. On October 23, Doris Angle went to the welfare

90. Id. at 895. A similar analysis applies to one of the two cases cited by Hartfield, supra note 77 , at 649-50, that refused to apply the UCCJA to adoptions. In Williams v. Knott, 690 S.W.2d 605 (Tex. Ct. App. 1985), the mother had remarried after the parties were divorced in Oklahoma, and the stepfather sought to adopt the child in Texas. The father, who continued to live in Oklahoma, the state that had issued the initial custody decree, objected that Oklahoma had continuing jurisdiction urider the UCCJA and the PKPA. The decision by the Texas court to uphold jurisdiction based on the Texas version of the UCCJA, id. at 607-08, was plainly wrong, not because the UCCJA does not apply to adoptions, but rather because section 14 of the Act prohibited Texas from taking jurisdiction to modify the father's custodial rights under the Oklahoma decree. In any event, Williams was criticized by a subsequent stepparent adoption case, White v. Blake, 859 S.W.2d 551, 562-63 (Tex. C. App. 1993), for refusing to recognize that "a suit to terminate parental rights includes as an element, a 'custody determination,' and may include 'child neglect proceedings' and is, therefore, a 'custody proceeding' as defined in [the Texas version of] the UCCJA." Id. at 563. Even with this correction, however, the Williams court should have deferred to the Oklahoma court, as indeed the White court defcrred to the Alabama court, which had granted the parties a divorce and entered the initial custody decree affecting the child.

91. 446 A.2d 871 (N.J. 1982), cert. denied, 459 U.S. 1210 (1983). A lower New Jcrsey court also relied on E.E.B. to apply the UCCJA and PKPA to adoption proceedings. See In re Adoption of Child by T.W.C. and P.C., 636 A.2d 1083, 1086-87 (N.J. Super. C. App. Div. 1994), discussed supra note 72 .

92. For this reason, Professor Hartfield correctly observes that E.E.B. is chiefly valuable as an analogy, rather than a precedent, for the application of the UCCJA to adoption procecdings. Hartfield, supra note 77, at 643.

93. Angle v. Children's Servs. Div., 407 N.E.2d 524 (Ohio 1980).

94. E.E.B., 446 A.2d at 873-80.

95. In re Clausen, 502 N.W.2d 649, 671-72, 680-81 (Mich.) (Levin, J., dissenting), stay denied sub nom. DeBoer by Darrow v. DeBoer, 114 S. Ct. 1 (Stevens, J.), and stay denied, 114 S. Ct. 11 (1993).

96. This statement of facts is taken from the Ohio Supreme Court's syllabus in Angle, 407 N.E.2d at 525-26. 
department and orally revoked her surrender of the baby. The welfare department did not inform the Ohio juvenile court of the mother's revocation, and on October 24 , the juvenile court approved the surrender. On December 29, the mother filed a petition for a writ of habeas corpus against the welfare department, seeking the return of her daughter.

The Ohio Supreme Court held that the mother had revoked her surrender of the baby before the juvenile court had approved the surrender, and that the welfare department's "continued retention of the child and refusal to return it to the natural parent is illegal and gives rise to an action in habeas corpus. ${ }^{.97}$ Accordingly, the Ohio Supreme Court directed the juvenile court to issue a writ of habeas corpus ordering the welfare department to return the child to the mother; the Juvenile Court did so on September 23, 1980.

While the Ohio proceedings were pending, the Bowens moved to New Jersey, where the husband had accepted a new job. ${ }^{98}$ On September 29,1980 , the Bowens initiated an action for custody in the Chancery Division of the New Jersey Superior Court. On December 1, the Chancery Division upheld its jurisdiction to hold a "best interests" hearing, which culminated in a finding that the child's best interests would be served by remaining with the Bowens. The mother appealed. ${ }^{99}$ The New Jersey Supreme Court recognized that Ohio had exercised jurisdiction properly, but proceeded nonetheless to strip the Ohio judgment of all force. First, it treated the juvenile court's habeas order as one that would have been modifiable in Ohio on a showing of the child's best interests. ${ }^{100}$ Second, the court interpreted the Ohio court's failure to conduct a best interests hearing before issuing the writ as a refusal to exercise jurisdiction under the PKPA, which left New Jersey "free to modify the Ohio decree."

In reaching this result, the New Jersey court failed to give full faith and credit to the Ohio judgment. The Ohio Supreme Court was acting on the mother's assertion of her legal right to custody of her child as against the Holmes County Welfare Department. The prospective adoptive parents, whose claim to the child's physical custody was derivative of the welfare department's right to place her, were not parties before the Ohio courts. In deciding the only operative question in the case, then, the Ohio Supreme Court ruled that because the mother had re-

97. Id. at 527 .

98. This statement of facts is taken from the opinion of the New Jersey Supreme Court in E.E.B., 446 A.2d at 87475 .

99. The mother had not participated in the best interests hearing, although she was notified of it, and she did not challenge the Chancery Court's finding on appeal. Id. at 874.

100. Id. at 877 .

101. Jd. 
voked her consent prior to the juvenile court's approval of her surrender, that surrender was void. The supreme court reasoned as follows:

In our opinion, to the extent that there can be no effective agreement relating to the transfer by a parent to the board of the permanent custody of a child without the consent of the Juvenile Court, pursuant to statute, there is, in effect, no agreement, but merely a proposed agreement, until court approval is obtained. (How can it be otherwise where disapproval by the court would be tantamount to nonexistence of the agreement?) Thus, in answer to the basic issue presented, unless and until a proposed agreement meets the approval of the Juvenile Court, no agreement as to permanent custody has been reached... and the proposed agreement is not only revocable by the parent prior to consent of the Juvenile Court, but this revocation operates to dissolve the offer to surrender and the public agency's continued retention of the child and refusal to return it to the natural parent is illegal and gives rise to an action in habeas corpus. ${ }^{102}$

The Ohio court went on to state that the procedural basis of its holding had rendered moot the constitutional issues raised by the mother. It concluded that "[f]or the reasons indicated, the writ of habeas corpus should have been allowed, and the appellant is entitled to custody of her child." 103 Again, this order was final and should have been recognized by the New Jersey Court.

The PKPA therefore had no proper role in the resolution of this case. Ironically, even if it had applied-that is, assuming that the prospective adoptive parents did have standing to seek custody even after the issuance of a habeas writ in Ohio-the PKPA would dictate that such a proceeding be brought in Ohio, not New Jersey. The view expressed by the New Jersey Supreme Court that "New Jersey, which has been the home of the child and parents for nearly three years, clearly has jurisdiction of the subject matter"104 flies in the face of the PKPA and cannot be sustained by that Act. ${ }^{105}$ Therefore, E.E.B. was for several

102. Angle v. Children's Servs. Div., 407 N.E.2d 524, 526-27 (Ohio 1980).

103. Id. at 527.

104. E.E.B. v. D.A., 446 A.2d 871,877 (N.J. 1982), cert. denied, 459 U.S. 1210 (1983).

105. The New Jersey court may have recognized that it was on tenuous ground in asserting jurisdiction, for it stated somewhat defensively that

[a] custody dispute is more than a jurisdictional chess game in which winning depends on compliance with predetermined rules of play. A child is not a pawn. In exercising its discretion within the confines of UCCJA and PKPA, a court should consider not only the literal wording of the statutes but their purpose: to define and stabilize the right to custody in the best interest of the child.

Id. at 879-80. To the contrary: the purpose of the UCCJA and the PKPA was precisely to establish "predetermined rules" that would prevent the contestants from turning the child's custody into a "pawn." 
reasons a highly suspect decision, and the majority in Baby Jessica's case correctly declined the invitation to follow it. ${ }^{105}$

In sum, the Gainey court not only misread Professor Bodenheimer's position, but it also improperly relied on both Souza and E.E.B. Unfortunately, several courts have nonetheless followed Gainey's reasoning, holding the UCCJA and the PKPA applicable to adoption proceedings. In doing so, some of these courts have relied on the Gainey court's misunderstanding of Bodenheimer, while others have followed Gainey's broad interpretation of the term "custody proceeding," which was mfluenced by that misunderstanding. ${ }^{107}$ None of

106. The majority stated:

We reject the rationale of E.E.B. v. D.A., to the extent that it is cited for the proposition that an order transferring custody pursuant to a judgment determining custody is modifiable per se on a best-interests analysis.... [T] $]$ his proposition, ... if accepted, would mean that an order granting custody would be enforceable only if the losing party voluntarily complied.... [It also] would invite the losing party to resist transfer.... Such a result would introduce a degree of instability into this jurisprudence antithetical to the best interests of all parties.

In re Clausen, 502 N.W.2d 649, 660 n.3I (Mich.), stay denied sub nom. DeBoer by Darrow v. DeBoer, 114 S. Ct. 1 (Stevens, J.), and stay denied, 1 I4 S. Ct. 1 I (1993).

I07. Some of these cases cite both Gainey and the Bodenheimer and Neeley-Kvarme article. For example, in State ex rel. Torres v. Mason, 848 P.2d 592 (Or. 1993), which involved a mandamus petition by the father to prevent an adoption in Oregon, the Oregon Supreme Court stated that the UCCJA does apply to adoption proceedings: "In a real sense, an adoption decree is the ultimate "custody determination." Id. at 593. The court held, however, that the Act did not confer jurisdiction on Oregon, since the divorce proceedings that granted custody to the mother had taken place in Washington, and the child had lived his entire life there except for one month spent with the prospective adoptive parents in Oregon. Id. at 595-96. Here, the UCCJA would have applied to prevent the Oregon court from affecting the initial Washington divorce custody proceeding, without regard to the fact that the pending Oregon proceeding was an adoption. The South Dakota Supreme Court, in In re Termination of Parental Rights over M.C.S., 504 N.W.2d 322, 325 (S.D. I993), found that the UCCJA applies to adoption proceedings, but that South Dakota lacked jurisdiction because the mother, husband, and putative father all lived in Iowa, where the child was born, and the mother had only brought the child to South Dakota to relinquish him to an adoption agency there. Id. at 322-23, 328. In Adoption of Zachariah K., 8 Cal. Rptr. 2d 423, 428 (Ct. App. 1992), a California Court of Appeal held that the UCCJA applies to adoption proceedings, but declined jurisdiction in favor of Oregon, where the child was taken immediately after birth by its prospective adoptive parents and where an adoption petition was pending. Id. at 428-30.

Other cases cite Gainey, but not the Bodenheimer and Neeley-Kvarme article. For example, the court in In re Adoption of Baby Girl B., 867 P.2d 1074, 1078 (Kan. Ct. App. I994), found the UCCJA applicable to adoption cases, but remanded the case for determination whether Kansas, where the natural mother lived with her uncle and where the adoption was pending, or Michigan, where the prospective adoptive parents lived with the child, was the more convenient venue. Id. at I078-80. Clark v. Gordon, 437 S.E.2d 144, 146 (S.C. Ct. App. I993), involved a stepparent adoption. The mother and father divorced in Kansas, which awarded joint custody of their daughter. After both parents moved away, Kansas declined further jurisdiction. The South Carolina Court of Appeals decided that first Missouri, then South Carolina, had become the child's "home state" under the UCCJA. The court remanded the case, however, for the trial court to determine whether the Missouri award of custody to the father without notice to the mother in South Carolina, where she and the child were living with the stepfather, was unfair and therefore invalid. Id. at 145-47. White v. Blake, 859 S.W.2d 551, 562 (Tex. Ct. App. 1993) concerned a mother and father who had divorced in Alabama, with the mother given custody of their child but allegatious of sexual abuse by the father found to be unsubstantiated. Id. at 553 . When the mother and her second husband attempted to 
these cases is sound authority for extending the UCCJA to adoption cases. They should not be followed by other courts. That most of these courts reached sound results despite their overbroad interpretation of the UCCJA and the PKPA, often by declining to assert the jurisdiction supposedly conferred upon them by those Acts and deferring to the court that had issued the initial decree, should not dispel criticism. We cannot rely on courts continuing to be able to "muddle through" to the right result while using faulty reasoning. In interstate adoption cases, there is a more predictable path to sound decision-making. This Article now explores that preferred path in the context of a fresh examination of the conflict of laws aspects of adoption cases.

III

\section{JURISDICTION AND RECOGNITION IN INTERSTATE ADOPTIONS}

As we have seen, ${ }^{108}$ child custody determinations following a divorce address different situations and perform different functions than do adoption proceedings. In the divorce situation, the spouses' marriage has been dissolved but their relationship to the child remains intact. The custody order commits the court to a supervision of the parent-child relationship that does not end until the child attains majority or becomes emancipated. Frequent adjustments may be required; hence, the order remains open to modification as circumstances change. In the adoption situation, by contrast, the court is called upon to sever the parental ties created by birth and to replace them with legal ties that will serve as the foundation for a new parent-child relationship. The court acts, then withdraws, leaving the newly formed family to function as it sees fit, subject to the same generalized standards that apply to all families.

Despite these differences, however, when either type of proceeding involves more than one state, some common issues arise. These are primarily issues involving jurisdiction in the forum state and recognition of the forum's judgment in other states. As noted above, adoption decrees are not modifiable, and thus should not encounter problems of finality. Divorce child-custody decrees, in contrast, remain vulnerable

terminate the father's parental rights in Texas preparatory to a stepparent adoption, the Texas courts held that the UCCJA required them to defer to Alabama, which had continued to exercise jurisdiction substantially in conformity with the UCCJA. Id. at 565. As in Mason, 848 P.2d 592, this reasoning would apply without reference to the stepparent adoption motion. Finally, the court in Fostcr v. Stein, 454 N.W.2d 244, 246 (Mich. Ct. App. 1990), held that adoption proceedings are included in the definition of a "custody proceeding" under the UCCJA because they are "in the nature of a dependency proceeding." Id. The court cited Gainey, but declined to exercise jurisdiction since the Florida courts had finally resolved the matter by deciding the appeal from the adoption. Jd. at 246-47.

108. See supra Part II.B.1-B.2. 
to revision by other states with a different view of the best interests of the child.

\section{A. Jurisdiction}

\section{Subject Matter Jurisdiction}

Analytically, interstate adoptions today occupy roughly the same position with respect to the forum's assertion of jurisdiction that interstate child custody determinations endured prior to the drafting of the UCCJA. State statutes regulating adoption have created overlapping subject matter jurisdiction among several states: ${ }^{109}$ the child's domicile, the residence of the child's birth parent or parents, the residence of the prospective adoptive parents, and the location of the adoption agency to whom the child has been relinquished. If rival proceedings to adopt the same child are commenced in more than one state, normal principles of res judicata will award priority to the judgment entered first. ${ }^{110}$ Under these conditions, forum shopping and a race to judgment are encouraged, while cooperation between courts to obtain complete information about the child's situation and circumstances is tacitly discouraged.

This unchecked jurisdictional conflict among states frustrates the central goal of interstate adoptions, which is to provide early and definitive resolution of the child's status and to assure stability in the parentchild relationship. In order to achieve this goal, the substantive law of adoption and the conflict of laws methodology of handling the cases must work together smoothly. Conflicts doctrine must not lend itself to the type of manipulation attempted in Baby Jessica's case, which is aimed at undercutting a definitive disposition reached under relevant substantive adoption law. Rather, conflicts doctrine should make plain the allocation of subject matter jurisdiction among potentially conflicting states in order to minimize disruption.

The child is the single constant focus of an adoption proceeding. Access to data concerning the child must play a central role in determining subject matter jurisdiction. Although the child need not be domiciled in a state in order for the adoption to proceed there, information concerning the child's adjustment in the home of the prospective adoptive parents must be made available to the court. This objective can be more easily attained if the adoption petition is filed in the state where the prospective adoptive parents are living with the child, than if the petition is heard in a state where the birth parents reside. In determining subject matter jurisdiction, the former state should have priority over other possible forums. Problems may arise if, for example, the birth

109. See Eugene F. SCOles \& Peter Hay, Conflict of Laws 559-61 (2d ed. 1992).

110. See Restatement (Second) of Judgments § 31 (1982); Restatement (Second) of CONFLICT OF LAWS $\$ 93$ (1971). 
parents are living in other states, and if either the non-consenting unwed father objects to the adoption, or the birth mother seeks to revoke her consent. However, even if one or both of these events occur, the subject matter jurisdiction of the adoption court should not be disturbed. At most, a choice of law problem may need to be resolved concerning which state's law determines how the objection or the revocation will be decided. ${ }^{111}$

111. Of course, in situations where the choice of law question presents a conflict of policy and interest between two or more states, the temptation to use overlapping jurisdictional provisions to secure the application of local law will be great. For example, in In re Adoption of Jarrett, 637 N.Y.S.2d 912 (App. Div. 1996), Pennsylvania, where the birth mother lived, and New York, where the prospective adoptive parents resided and where they filed the adoption petition, had different laws concerning the revocation of consent and the circumstances under which the birth father may object to the adoption. Jill Hayden, the birth mother, surrendered her son for private adoption four days after his birth in Pennsylvania on April 6,1995. She had concealed the birth, and perhaps the pregnancy as well, from the birth father, Steven W. Johnson. The prospective adoptive parents, Karen and Dennis Doe, took the baby home with them to New York, where they initiated adoption proceedings on April 13. On April 14, Jill wrote a letter to the New York court, revoking her consent to the adoption. Six days later, she executed a formal withdrawal of consent. On April 26, the birth father, who had learned of the situation, joined the birth mother in filing a complaint in the Pennsylvania Court of Common Pleas seeking custody of Baby Boy Jarrett.

Under Pennsylvania law, the birth father's consent to an adoption is required unless his rights have been terminated or he has abandoned the child. See Adoption of Walker, 360 A.2d 603 (Pa. 1976) (invalidating under the equal rights provision of the Pennsylvania state constitution (Art. l, sec. 28) a statute requiring the consent to an adoption only of the unwed mother, but not the unwed father of a child). Under New York law, however, a birth father who has not lived with the mother and his newborn child may object to an adoption only if he has demonstrated a "qualifying interest" in the child by showing the "willingness himself to assume full custody of the child-not merely to block adoption by others," and, in the six months immediately prior to the adoptive placement, there must be evidence of his "prompt manifestation of parental responsibility." See In re Raquel Marie X, 559 N.E.2d 418, 428 (N.Y.), cert. denied, 498 U.S. 984 (1990) (invalidating N.Y. DOM. REL. LAW \& 111(1)(e) (McKinney 1988), which had imposed a "living together" requirement on the father). Moreover, Pennsylvania law provides that "a natural parent's consent to an adoption may be withdrawn at any time before entry of a final decree," Adoption of Gunther, 206 A.2d 61, 63 (Pa. 1965), and if consent is so revoked, the birth parent is entitled to have the child returned without a "best interests" hearing, providing there is no finding of abandonment, see Adoption of Jacono, 231 A.2d 295, 296 ( $\mathrm{Pa}$. 1967). New York law, by contrast, provides that a birth parent's consent to an adoption is irrevocable if given in court, and if given out of court, as in this case, may be revoked within $\mathbf{4 5}$ days. A best interests hearing ensues if, as in this case, the prospective adoptive parents challenge the revocation. See N.Y. DOM. REL. LAw \& 115-b(6)(d)(i) (McKinney 1988).

In response to the birth parents' complaint, the Pennsylvania Court of Common Pleas entered an order finding (incorrectly, see supra text accompanying notes 54-71) that Pennsylvania was the child's "home state" under the UCCJA, and dismissing the prospective adoptive parents' preliminary objections as to jurisdiction. See Johnson v. Herman, No. 665 of 1995-D (Ct. of Common Pleas, Westmoreland County., Pa, Aug. 28, 1995) (copy on file with author). The New York Family Court subsequently dismissed the adoption petition, finding, among other things, that it lacked pcrsonal jurisdiction over the birth father, that the birth mother had been inadequately represented by counsel, and that, in addition, it could not proceed with the adoption because the birth mother's original consent was never filed with the court. It granted custody of Baby Boy Jarrett to the birth mother. See In re Adoption of Jarrett, 638 N.Y.S. 2 d 866 (Fam. Ct. 1995).. This order was reversed by the Appellate Division of the New York Supreme Court in the opinion eited above, and the mattcr was remanded for further proceedings. 


\section{Jurisdiction Over the Parties}

Adoption cases, like other civil proceedings, present an essential problem of personal jurisdiction: whether the court has power to decide the matter so that its judgment will foreclose collateral attacks at a later time. Finality is, among other things, a product of the valid assertion of judicial power. When the matter to be decided involves severing the child's legal ties to the birth parents by court order and forming new ties with a set of adoptive parents, the consent of one or both birth parents must be obtained or found unnecessary. The most controversial problem of personal jurisdiction in current adoption cases is whether personal jurisdiction over a non-consenting birth parent-almost always the child's unwed father-is necessary to foreclose that parent from attacking the judgment.

The overwhelming majority of children available for adoption by nonrelatives are born to single mothers who do not wish, or are not able, to raise them alone. ${ }^{112}$ In this group of adoptions, which includes the cases of both Baby Jessica and Baby Richard, the birth mothers typically have surrendered their babies for adoption, and their consent to the adoption has been secured before the court petition is filed. Prior to 1972 , the consent of the birth mother alone was sufficient to authorize a court to proceed with the adoption. ${ }^{113}$ The other birth parent-the unwed father-had no right to object to the mother's decision unless he had legitimated the child. ${ }^{114}$ In these circumstances, no problem of personal jurisdiction over the birth parents arose. The mother's consent made her participation in the court proceeding unnecessary, and the father lacked standing.

Unhappily, Baby Boy Jarrett appears to be headed for the same interstate jurisdictional conflict, based on a similar misreading of the UCCJA, that Baby Jessica endured. A preferable outcome would be for the New York Family Court, assuming it does have personal jurisdiction over the birth father, to retain subject matter jurisdiction based on its contacts with the prospective adoptive parents and the child and to resolve the choice of law questions promptly. If the New York court cannot accomplish this task consistent with constitutional standards of due process either because it lacks in personam jurisdiction over the father, see infra text accompanying notes 136-142, or because it lacks sufficient contacts with him to euable it to apply New York law to decide whether he has a right to object to the adoption, see Home Ins. Co. v. Dick, 281 U.S. 397 (1930) (holding that due process prevented Texas from applying Texas law to a contract of insurance made and to be performed in Mexico or New York), then it should dismiss the adoption proceeding and permit Pennsylvania to resolve the matter. A confrontation in which both states assert jurisdiction in order to apply local law will merely result in a race to judgment. That will resolve the matter, to be sure, but only at the greatest possible detriment to all parties involved, and in a fashion likely to produce appeals to the respective high courts of both states as well as petitions for certiorari to the United States Supreme Court.

112. See homer H. Clark, Jr., The Law of Domestic Relations in the United States 852 (2d ed., student ed., 1988) (noting, additionally, that the number of such children available for adoption has been declining for several years).

113. Id. at 855 .

114. Id. 
The United States Supreme Court's 1972 decision in Stanley v. Illinois, ${ }^{115}$ holding that an unwed father was entitled to a hearing on his fitness to have custody of his child following the mother's death, spelled the end of this aspect of adoption law and practice. Although a series of subsequent Supreme Court cases further developed the rights of unwed fathers, ${ }^{116}$ commentators have not read these cases to require that the adoption court have personal jurisdiction over the unwed father in order to proceed with the case. ${ }^{117}$ All that has been thought necessary is that any unwed father with the legal right to object to the adoption be given proper notice of the proceeding and afforded an opportunity to be heard. ${ }^{118}$

This accepted understanding, however, may be open to constitutional challenge. Although the United States Supreme Court has never held that a court must have personal jurisdiction over an unwed father in order to deprive him of the right to object to his child's adoption, the Court's decision in May v. Anderson, ${ }^{119}$ handed down in 1953 by a

115. 405 U.S. 645 (1972).

116. See, e.g., CLARK, supra note 112, at 855-61 (discussing Quilloin v. Walcott, 434 U.S. 246 (1978); Caban v. Mohammed, 441 U.S. 380 (1979); and Lehr v. Robertson, 463 U.S. 248 (1983)) in light of Stanley); see also infra text accompanying notes 136-139.

117. See, e.g., ClaRK, supra note 112, at 861-62.

118. Id. at 862-65. Both state and federal law determine whether a birth parent has the legal right to object to an adoption. Until the United States Supreme Court's decision in Stanley, 405 U.S. 645 , the birth father of a child bom out of wedlock lacked standing to object to the child's adoption. The birth mother of a child born out of wedlock had the power, acting alone, to consent to the adoption. Current constitutional law has eliminated this earlier sex-based distinction between fathers and mothers, see Caban, 441 U.S. 380 (holding that birth father who had jointly parented child with birth mother was denied equal protection by state statute dispensing with his consent to adoption by stepfather), but has required that the birth father act on the opportunity to form a parental relationship with his child and accept some measure of responsibility for the child's future in order to merit constitutional protection, see Lehr, 463 U.S. 248. States have interpreted this requirement more or less stringently. Compare Nale v. Robertson, 871 S.W.2d 674 (Tenn. 1994) (finding that birth father who told birth mother during pregnancy that he wanted custody of the baby if she should choose to give the child up for adoption, but who was not notified when the mother surrendered the child two days after birth, has a right to be heard on his petition to legitimate the child), noted in Clarissa $M$. Cissell, Adoption-Nale v. Robertson: The Tennessee Supreme Court Expands the Parental Rights of Putative Fathers, 25 U. MEMPHIS L. REv. 1521 (1995), with Adoption of Michael H., 898 P.2d 891, 901 (Cal. 1995) (holding that birth father who joined in planning for adoption with birth mother, but who did not communicate to the birth mother or the prospective adoptive parents with whom she was living his opposition to the adoption until two weeks after the child's birth, had failed to show "that he promptly came forward and demonstrated as full a commitment to his parental responsibilities as the biological mother allowed and the circumstances permitted within a short time after he learned or reasonably should have learned that the biological mother was pregnant with his child"). Recent advances in reproductive technology have unsettled the previously stable law concerning which woman qualifies as the "birth" mother: the surrogate mother or the genetic mother. See Johnson v. Calvert. 851 P.2d 776 (Cal.), cert. denied, 114 S. Ct. 206, and cert. dismissed, 114 S. Ct. 374 (1993) (holding that genetic mother, not surrogate birth mother, was "natural mother" of child); see generally Marjorie M. Shultz, Reproductive Technology and Intent-Based Parenthood: An Opportunity for Gender Neutrality, 1990 WIS. L. REV. 297.

119. 345 U.S. 528 (1953). 
badly fragmented bench, ${ }^{120}$ can be read to suggest that personal jurisdiction over a mother is indeed required in order to deprive her of the custody of her children in a divorce proceeding. By extension, it would appear to follow that personal jurisdiction over either parent should be mandatory in any proceeding in which that parent's custodial rights might be affected. This proposition would be given even more weight in adoption proceedings than in divorce child-custody cases, because an adoption judgment terminates the birth parents' rights. Because of the difficulty in identifying or locating the unwed birth father in many cases, however, if personal jurisdiction were required over him, then interstate adoption cases would appear to be vastly more difficult to resolve. Even if he were identified, if he refused to appear, one can imagine cases in which no state could legitimately assume jurisdiction over all parties. Much hinges, then, on what precisely it is that the Court decided in May v. Anderson.

In May, the mother and father married in Wisconsin and lived there with their three children until marital problems developed in December 1946. With her husband's consent, the mother went to Ohio with the children and soon decided not to return to Wisconsin. The husband commenced divorce proceedings in Wisconsin, seeking termination of the marriage and custody of the children. Substituted service was made on the mother in Ohio, but she did not appear in the Wisconsin proceedings. The Wisconsin court granted the father a divorce and custody of the children while giving the mother reasonable visitation rights. The father retrieved the children from Ohio and lived with them in Wisconsin until 1951. In July 1951, when the children visited their mother in Ohio, she refused to permit them to return to Wisconsin. The father commenced a habeas corpus action, which in Ohio tested only the immediate right to legal possession of the children, not possible modification of the Wisconsin custody order on the basis of changed circumstances. ${ }^{121}$

In the United States Supreme Court, Justice Burton wrote for a plurality that Wisconsin lacked power to affect the absent mother's right to immediate custody of her children without obtaining personal jurisdiction over her. Invoking the precedent of jurisdictional requirements in ex parte divorce cases, Burton reasoned as follows:

Separated as our issue is from that of the future interests of the children, we have before us the elemental question whether a

120. Justice Burton wrote a plurality opinion joined by three other Justices: Chief Justice Vinson and Justices Black and Douglas. Justice Frankfurter concurred separately. Justices Jackson and Reed authored one dissent, while Justice Minton dissented separately. Justice Clark did not participate.

121. May, 345 U.S. at 530-32. 
court of a state, where a mother is neither domiciled, resident nor present, may cut off her immediate right to the care, custody, management and companionship of her minor children without having jurisdiction over her in personam. Rights far more precious to appellant than property rights will be cut off if she is to be bound by the Wisconsin award of custody....

In Estin v. Estin, [334 U.S. 541 (1948)], and Kreiger v. Kreiger, [334 U.S. 555 (1948)], this Court upheld the validity of a Nevada divorce obtained ex parte by a husband, resident in Nevada, insofar as it dissolved the bonds of matrimony. At the same time, we held Nevada powerless to cut off, in that proceeding, a spouse's right to financial support under the prior decree of another state. In the instant case, we recognize that a mother's right to custody of her children is a personal right entitled to at least as much protection as her right to alimony.

... We find it unnecessary to determine the children's legal domicile because, even if it be with their father, that does not give Wisconsin, certainly as against Ohio, the personal jurisdiction that it must have in order to deprive their mother of her personal right to their immediate possession. ${ }^{122}$

Justice Frankfurter, concurring, took a different view. He stressed Wisconsin's competence to deny custody, not Ohio's compulsion to respect or reject Wisconsin's disposition:

What is decided - - the only thing the Court decides-is that the Full Faith and Credit Clause does not require Ohio, in disposing of the custody of children in Ohio, to accept, in the circumstances before us, the disposition made by Wisconsin. The Ohio Supreme Court felt itself so bound. This Court does not decide that Ohio would be precluded from recognizing, as a matter of local law, the disposition made by the Wisconsin court. For Ohio to give respect to the Wisconsin decree would not offend the Due Process Clause. Ohio is no more precluded from doing so than a court of Ontario or Manitoba would be, were the mother to bring the children into one of these provinces. ${ }^{123}$

Justice Jackson made clear in his dissent the havoc that would be created in child custody cases if a literal interpretation of the plurality opinion were accepted:

The Court's decision holds that the state in which a child and one parent are domiciled and which is primarily concerned about his welfare cannot constitutionally adjudicate controversies as to his guardianship. The state's power here is defeated by the absence of the other parent for a period of two months. The convenience of a leave-taking parent is placed above the welfare

122. Id. at 533-34 (plurality opinion) (footnotes omitted).

123. Id. at 535-36 (Frankfurter, J., concurring). 
of the child, but neither party is greatly aided in obtaining a decision. The Wisconsin courts cannot bind the mother, and the Ohio courts cannot bind the father. A state of the law such as this, where possession apparently is not merely nine points of the law but all of them and self-help the ultimate authority, has little to commend it in legal logic or as a principle of order in a federal system. ${ }^{124}$

Because Justice Frankfurter's vote was necessary to produce a majority of the court, his concurrence has been taken as the holding of the case. ${ }^{125}$ Professor Geoffrey C. Hazard, Jr., in a scathing critique of the case, demonstrated that neither the Burton due process approach nor the Frankfurter full faith and credit alternative was analytically coherent or justifiable on policy grounds:

Under the view adopted by Justice Burton, the second court is required to ignore the first decree if the parent adversely affected was not a party thereto. This is so, of course, because the first court was without jurisdiction and its decree is a nullity. If this is to be taken as the law, a parent could be advised to stay away from any custody proceeding in which his chances of success appear to be in the slightest degree less than his chances of success in some other court.

Under the Frankfurter view in May $v$. Anderson, the parent has even wider choice. He can appear in the first court, litigate to the bitter end, and if he loses, simply take the child to some other state and start all over again. In sum, under the majority's rule parents may ignore the courts; under the rule of the concurrence, they may defy them.

In these circumstances, how "precious" is the parental right of custody? What value attaches to a right that is not worth the paper on which it is written? How much is a child protected under a system of rules which encourages his parents to redetermine his custody frequently, forcibly, and extra-legally? It seems quite clear that in its ill-considered efforts to maximize protection of parental rights and to protect the interest of children, the Court has dealt a crushing blow to both. ${ }^{126}$

Hazard concluded fiatly that the decision in May $v$. Anderson was a "mistake" that warranted judicial re-examination. ${ }^{127}$ Yet the Supreme Court has not acted on his suggestion in the forty-plus years since the case was handed down. Although the Court has continued to cite the

124. Id. at 539 (Jackson, J., dissenting).

125. Bodenheimer, supra note 36, at 1232; see also RESTATEMENT (SECOND) OF CONFLICT OF LAws $\S 79 \mathrm{cmt}$. c (1971) (accepting the Frankfurter interpretation as authoritative).

126. Geoffrey C. Hazard, Jr., May v. Anderson: Preamble to Family Law Chaos, 45 VA. L. Rev. 379, 394-95 (1959) (footnotes omitted); see also CLARK, supra note 112, at 460-63.

127. Hazard, supra note 126, at 406. 
result, ${ }^{128}$ it has never made clear which opinion it considers controlling, and therefore has never explicitly decided whether a court must have personal jurisdiction over an absent parent in order to rule in a custody dispute. The drafters of both the UCCJA ${ }^{129}$ and the UAA, ${ }^{130}$ however, acted on the assumption that the Frankfurter interpretation was controlling-that is, that personal jurisdiction over the absent parent was unnecessary. The drafters of the UCCJA feared that giving credence to the Burton opinion would displace the "home state" as a state of initial jurisdiction whenever it lacked personal jurisdiction over an absent parent. This would have disrupted the Act's insistence on having the custody adjudication made in a state with maximum access to information about the child, and would have doomed the Act to failure. The drafters of the UAA adopted this position in reliance on the UCCJA format.

A plausible argument can be made, however, that critics have overestimated the potential disruptive force contained in May $v$. Anderson. They have failed to recognize that a habeas corpus proceeding involves different considerations from a proceeding to enforce a modifiable sister-state judgment. At the moment of separation in 1947, both parents had an equal right to the custody of their children. The mother did not abscond with the children to Ohio. She left with the father's consent. When the Wisconsin court, acting on the father's petition, awarded him a divorce and custody of the children, it did not "cut off" the mother's right to custody. Indeed, she was awarded "reasonable" visitation rights. When the father appeared in Ohio in 1947 and demanded physical possession of the children, the mother did not forfeit her visitation rights by relinquishing the children to him. That she did not avail herself of the opportunity to visit the children in Wisconsin does not, by itself, mean that she abandoned them. Thus, when the father brought

128. See, e.g., Kulko v. Superior Court, 436 U.S. 84, 97 (1978).

129. See UCCJA § 3, 9 U.L.A. pt. 1, at 143-44; UCCJA § 4, 9 U.L.A. pt. 1, at 208; UCCJA § 5, 9 U.L.A. pt. 1, at 212 (1988). Professor Bodenheimer has disclosed that the Commissioners on Uniform State Laws, in drafting the UCCJA, decided to base the Act on the Frankfurter interpretation: "that other states are authorized to recognize as binding on their resident a custody decision of another state in which personal jurisdiction over this resident was not obtained." Bodenheimer, supra note 36, at 1232. Bodenheimer and Neeley-Kvarme re-evaluated this decision in light of two Supreme Court decisions handed down in the late 1970s, one of which subjected traditional in rem jurisdiction to a general standard of faimess, see Shaffer v. Heitner, 433 U.S. 186 (1977), while the other invalidated as "unreasonable" the assertion of in personam jurisdiction over a nonresident father in a child support case, see Kulko, 436 U.S. 84. The authors addressed the Court's rejection of any suggestion that "jurisdictional doctrines other than those discussed in text [sic], such as the particularized rules goveming adjudication of status, are inconsistent with the standard of faimess." Bodenheimer \& Neeley-Kvarme, supra note 43, at $239-40$ (quoting Shaffer, 433 U.S. at 208 n.30) (alteration in original). They concluded that the Court's reasoning was broad enough to permit states to rely on the UCCJA's detailed scheme for child custody determinations without requiring personal jurisdiction over an absent parent. See id. at 251.

130. See UAA \$ 3-101, 9 U.L.A. pt. 1, at 39-40 (Supp. 1995). 
the children to Ohio in 1951, she retained her parental rights as their mother, subject only to the father's right as primary custodian under the Wisconsin decree.

Viewed in this light, the mother's refusal to return the children to the father at the conclusion of their visit posed a strategic problem for the father. If he had initiated proceedings in Ohio to enforce the Wisconsin custody decree, the mother would have been given the opportunity to argue that circumstances had changed in the four-andone-half years since that decree was entered and that custody should now be awarded to her. The father would then bear the risk of persuading a possibly unfriendly court located in the mother's territory that he should be allowed to retain custody. The father decided not to take that risk. He chose instead to use the Ohio procedure that tested only the parents' respective legal rights to physical possession of the children, no doubt on the assumption that the Wisconsin decree, as the only extant adjudication of that issue, would be entitled to recognition.

From this perspective, Justice Burton's plurality opinion takes on a more limited meaning than its critics have allowed. The "elemental question" before the court becomes whether Wisconsin could terminate the mother's naked legal right to the "immediate possession" of her children without acquiring in personam jurisdiction over her-not the more general question whether without personal jurisdiction Wisconsin could adjudicate the children's "future interests" in a proceeding that allowed the mother to seek re-evaluation of that adjudication at a later time. In light of the restrictive writ chosen by the father, Burton may have meant no more than that Wisconsin could not permanently deprive the mother of her legal rights as a parent without having personal jurisdiction over her. Contrary to the critics' interpretation, the plurality opinion would not then stand for the proposition that Wisconsin lacked power to make a non-final award of the children's custody to the father while still recognizing the mother's continuing, but reduced, parental right to visitation.

If this analysis is correct, then Frankfurter's concurrence becomes less mysterious. It can be understood merely as an obvious correction of Justice Jackson's overly broad reading of the plurality opinion. Frankfurter was at pains to point out that, although Ohio was not "bound" by the Wisconsin decision, neither was it precluded from voluntarily according the decision recognition. Ohio's freedom to choose arose not because the Wisconsin decree was void for lack of personal jurisdiction over the mother, but because the decree did not terminate her legal status as a parent who had an "immediate" right to possession of her children subject to further proceedings concerning their "future interests." 
This interpretation of May $v$. Anderson is supported by the dissenting opinion of Justice Minton, who argued that both the Court and the Jackson dissent "deal[t] with a jurisdictional question not raised on the record." 131 He spelled out his argument by noting that, in Ohio, "... [i]t is well settled that habeas corpus is not the proper or appropriate action to determine, as between parents, who is entitled to the custody of their minor children."

The instant case was a proceeding in Ohio by habeas corpus brought by the father against the mother for the possession of the minor children. The father could not succeed in this habeas corpus action unless he could show that he had an order of a court of competent jurisdiction awarding him the custody of the children. He produced an authenticated copy of a [Wisconsin] decree ... valid on its face and unappealed from, which awarded him the custody of the children. It is not contended that this decree is void upon its face, nor did appellant, the mother, challenge its validity in Ohio by any responsive pleading to the petition for habeas corpus. ${ }^{132}$

For Minton, the conclusion followed that, as the validity of the Wisconsin decree had not been challenged, it was entitled to full faith and credit in the Ohio habeas proceeding. ${ }^{133}$

The foregoing analysis suggests that Justice Burton would have required personal jurisdiction over a nonresident parent only in a proceeding in which that parent's legal rights to a child's custody might be terminated. He would have left open the question whether personal jurisdiction is required in a less-invasive proceeding that merely allocates custody. Read in procedural context, Burton's opinion says only that the state of the father's domicile may not, as against the state of the mother's domicile, permanently deprive the mother of her legal rights as a parent. Frankfurter's concurrence then simply makes clear that the mother's state of domicile may, while continuing to respect her ongoing parental rights, voluntarily give recognition to the decision of the father's state allocating the continuing custodial rights of both parents.

If May v. Anderson is interpreted along these lines, the drafters' decision not to require in personam jurisdiction over the parties in divorce child-custody decisions subject to the UCCJA is entirely reasonable. While a decision sustaining the writ of habeas corpus in May v. Anderson would have, as Justice Burton put it, improperly "cut off" the mother's immediate right to custody, ${ }^{134}$ it would not have terminated her "reasonable" visitation rights. Even if the mother had

131. May v. Anderson, 345 U.S. 528, 542 (1953) (Minton, J., dissenting).

132. Id. at 542-43 (quoting In re Corey, 61 N.E.2d 892, 894-95 (Ohio 1945) (citation omitted)).

133. Id. at 543 .

134. Id. at 533 (plurality opinion). 
been forced to relinquish the children to the father in Ohio, she could have sought a redetermination of the children's future custody in a subsequent proceeding brought in either Ohio or Wisconsin. Although Justice Jackson's observation that Wisconsin could not bind the mother any more than Ohio could bind the father may have been accurate at the time, it seems clear today that a long arm statute drafted to extend the state's judicial power to the limits of the Due Process Clause would easily permit a state in Wisconsin's position to obtain in personam jurisdiction over the mother. The other half of Jackson's observation probably remains accurate today: Ohio would likely still be unable to compel the appearance at custody proceedings of someone with the father's lack of prior contacts with the state. ${ }^{135}$

Adoption presents a different situation. Even if the UCCJA may constitutionally dispense with a requirement of in personam jurisdiction over an absent parent in divorce child-custody cases, it does not follow that the UAA may do so. Unlike divorce-related proceedings, adoption cases permanently terminate a parent's right to seek custody, regardless of whether circumstances change in the future. Precisely because adoptions do terminate parental rights, the due process safeguard that a requirement of personal jurisdiction represents should be available to parents who meet the conditions specified below. ${ }^{136}$

Arguments may of course be raised on the other side of this issue. First, although Stanley v. Illinois cited with approval Justice Burton's observation in May v. Anderson that parental rights are "far more precious" than property rights, ${ }^{137}$ it did not otherwise suggest that in personam jurisdiction, as distinguished from the right to be heard on the issue of parental fitness, is constitutionally required. Second, Professor Clark, a leading family law expert, has argued strenuously that nothing more than notice is necessary, stating that any other result would be "so destructive of adoption practice" that courts would likely continue their current tactic of seeming "just to be ignoring it." 138

Both of these objections may, however, be countered. First, the Court has not explicitly stated, in Stanley or anywhere else, that personal jurisdiction is not constitutionally required in cases involving termination of parental rights. Second, Clark's conclusion is overstated, given the restrictions that have been placed on an unwed father's standing to object to an adoption that the mother has approved. The expansive

135. See Kulko v. Superior Court, 436 U.S. 84, 101 (1978) (holding that California lacked personal jurisdiction over a New York father whose only contact with the state was allowing his child to go there to live with the mother).

136. See infra text accompanying note 139 .

137. Stanley v. Illinois, 405 U.S. 645, 651 (1972) (quoting May v. Anderson, 345 U.S. 528, 533 (1953)).

I38. ClARK, supra note 112 , at 862. 
right to be heard on the issue of parental fitness created in 1972 by Stanley has been narrowed in the adoption context to benefit only those unwed fathers who have come forward, identified themselves, grasped the opportunity to develop a relationship with their child, and accepted "some measure of responsibility for the child's future." 39 If May $v$. Anderson were now read to require that a court hearing an adoption must have in personam jurisdiction over this class of unwed fathers in order to terminate their parental rights, surely the effect would not be "destructive of adoption practice." Such fathers already must be given notice and afforded the opportunity to object to the adoption. Only those who choose not to avail themselves of this opportunity would potentially create any additional difficulty. . The problem would then come to this: a court having subject matter jurisdiction as the state in which the prospective adoptive parents are living with the child might not be able to proceed if the father has had no contact with the state such that it could summon him to appear and assert his objections.

This problem is not insoluble, although effectively addressing it would require some change in existing law. The Commissioners on Uniform State Laws have already developed at least one model statute that addresses the situation where a court in one state has jurisdiction over one party and a court in a different state has jurisdiction over the other party. The Uniform Reciprocal Enforcement of Support Act (URESA) ${ }^{140}$ calls upon the two courts in this situation to cooperate in entering a judgment. Under URESA, the initiating state, with jurisdiction over the party who will receive support payments, and the responding state, with jurisdiction over the party who will pay the support, together can impose, enforce, and modify child and spousal support orders. URESA has been adopted in some form in all fifty states. ${ }^{141}$ Its mechanism could easily be imported into a statute treating interstate adoptions - the UAA, for example - to handle the problems that might arise from an unwed father's objections based on lack of in personam jurisdiction.

In sum, the termination of a parent's legal rights of association with his child, particularly where a relationship of the sort required by the

139. Lehr v. Robertson, 463 U.S. 248,262 (1983). The Court has left open whether fathers of newborn infants are entitled to be given the same treatment as mothers of newborns, who can consent to the child's adoption. See Caban v. Mohammed, 441 U.S. 380, 392 n.11 (1979).

140. 9B U.L.A. 381 (1987) (1968 Revised Act) and 9B U.L.A. 553 (1987) (1950 Act, as amended in 1952 and 1958).

141. See SCOLES \& HAY, supra note 109 , at 533. In 1992, the Commissioners promulgated the Uniform Interstate Family Support Act (UIFSA), which supersedes URESA and RURESA. Historical Note, 9 U.L.A., pt. 1, at 229 (Supp. 1995). UIFSA contains a long-arm provision designed to obtain jurisdiction over a nonresident respondent (section 201, at 242) and thus to collapse the two-state procedure into a one-state procedure, but it also retains the two-state procedure (section 203, at 245) as a back-up. See Comment to section 201, at 242-43. 
Supreme Court as the threshold for recognition of these rights has been established, should be undertaken only in a court that directly or through reciprocal action with a second court can compel that parent's presence before the court. To do so will honor the parent-child relationship without undermining the effectiveness of adoption as a way of providing for the interests of children. ${ }^{142}$

\section{B. Recognition}

A judgment granting or denying an adoption, entered by a court with proper jurisdiction over the subject matter and the parties, is a final judgment entitled to recognition in other states. ${ }^{143}$ This proposition is noncontroversial as applied to a judgment granting an adoption, ${ }^{144}$ but it has been questioned by prospective adoptive parents seeking to escape the effect of a judgment denying an adoption. Attempts to avoid the force of a judgment denying an adoption rest on a claim that the judgment is modifiable. Thus, some parties, as in the case of Baby Jessica, have invoked the UCCJA as permitting a second state to "modify" the "custody determination" that required the prospective adoptive parents to return the child to the birth parents. ${ }^{145}$ Such use of the UCCJA is improper. Though in some ways similar to a divorce child-custody order, an order compelling the prospective adoptive parents to release the child to the birth parents simply is not a "custody proceeding" within the meaning of the UCCJA. Therefore, the order is not modifiable under that Act, or, for that matter, under any other statute.

Unfortunately, courts have continued to entertain "modifications" of these unmodifiable final orders. In re Custody of K.R. ${ }^{146}$ provides a recent illustration of this type of recognition problem. The case involved essentially the same improper application and faulty analysis of the UCCJA that characterized the Michigan proceedings in Baby Jessica's case. ${ }^{147}$ K.R.'s parents lived in Colorado, but the mother moved to California to live with her sister during lier pregnancy. K.R.

142. Such a requirement is consistent with theories that undertake a reconceptualization of fathers' rights in an effort to achieve equality between women and men in the context of family law. See Deborah L. Forman, Unwed Fathers and Adoption: A Theoretical Analysis in Context, 72 TEx. L Rev. 967 (1994); Mary L. Shanley, Unwed Fathers' Rights, Adoption, and Sex Equality: GenderNeutrality and the Perpetuation of Patriarchy, 95 Colum. L REv. 60 (1995).

143. See SCOLES \& HAY, supra note 109, at 561-62.

144. A discussion addressing whether other states will recognize all of the incidents of adoption, as defined by the law of the state granting the adoption, or whether other states may modify or supplement those incidents, is beyond the scope of this article. See CLARK, supra note 112, at 928-30, for a treatment of the custody, support, and visitation issues that accompany the granting of an adoption decree.

145. See supra text accompanying notes 20-26.

146. 897 P.2d 896 (Colo. Ct. App. 1995).

147. See supra text accompanying notes 20-26. 
was born in California on December 18, 1993, and was privately placed for adoption with a California couple, who took the infant home with them from the hospital. Adoption proceedings were commenced in California. ${ }^{148}$

The birth mother, who had returned to Colorado, changed her mind about the adoption two-and-one-half months after the child's birth. Efforts at mediation failed, and on April 13, 1994, the birth mother signed a "Refusal to Consent to Adoption" form. Pursuant to a state statute, ${ }^{149}$ the California court ordered that "the "care and custody of the minor' be immediately restored to the biological mother." 150

Instead of obeying the order of the California court, the prospective adoptive parents shifted their focus to Colorado, where they filed a petition for custody of the child. The Colorado trial court dismissed this petition on the ground that the adoption decree was a "custody decree" entitled to full faith and credit. In doing so, the trial court reached the correct result but improperly characterized the California court's order, which was not of course a (modifiable) "custody decree" but a final order. The California adoption statutes provided at the time that when a court approved the birth parent's withdrawal of consent to the adoption in a private placement, the adoption proceeding "shall be dismissed." Wh1 While this order deprives the prospective adoptive parents of "custody," it does so because the adoption petition is dismissed for failure to obtain the birth parent's consent. The order is a final judgment confirming the child's status as the child of the birth parent. As such, the California court's decree was indeed entitled to full faith and credit.

The trouble is that the Colorado trial court did not stop there. Over the objections of the prospective adoptive parents, ${ }^{152}$ it next determined

148. In re K.R., 897 P.2d at 898-99.

149. See CAL. FAM. CODE $\S 8815$ (Deering 1994) (first of two; operative until Jan. 1, 1995):

(d) ... If the court finds that withdrawal of the consent to adoption is reasonable in view of all the circumstances and that withdrawal of the consent is in the child's best interest, the court shall approve the withdrawal of the consent. Otherwise, the court shall withhold its approval. Consideration of the child's best interest shall include, but is not limited to, an assessment of the child's age, the extent of bonding with the prospective adoptive parent or parents, the extent of bonding or the potential to bond with the birth parent or parents, and the ability of the birth parent or parents to provide adequate and proper care and guidance to the child. If the court approves the withdrawal of consent, the adoption proceeding shall be dismissed.

Given this section's standard for approving the birth parent's motion to withdraw consent to the adoption, the trial court properly ordered the child to be returned to the parent's "care and custody" following the dismissal of the adoption petition.

150. In re K.R., 897 P.2d at 899.

151. See supra note 149.

152. It is not self-evident why the prospective adoptive parents chose not to rely on the UCCJA, while at the same time seeking a new custody proceeding in Colorado. They may have been seeking 
that California was the child's "home state" under the UCCJA, and that Colorado lacked jurisdiction under that Act, or, if it had jurisdiction, that it would decline to exercise that jurisdiction "because it believed that the California court was the more appropriate forum."153 In taking this position, the Colorado trial court misconstrued both the nature of the California adoption proceedings and the UCCJA.

First, the California court had not proceeded under the UCCJA. It acted, properly, under the California statutes that regulate private placement of children for adoption. ${ }^{154}$ Second, even if the UCCJA applied in this case-which it did not-California was not the "home state" under the terms of the Act. ${ }^{155}$ For the same reasons that neither the District of Columbia nor California could qualify as the child's "home state" in Baby Boy Rogers's case, ${ }^{156}$ California could not be the "home state" in K.R.'s case: the child had not lived in California in any of the parties' custody "from birth" to the time immediately preceding the filing of the proceeding.

In affirming the trial court's decision that Colorado lacked subject matter jurisdiction over the case under both the UCCJA and the PKPA, the Colorado Court of Appeals followed the cases criticized earlier in this Article ${ }^{157}$ that had misinterpreted both Acts to apply to adoption cases. It first decided incorrectly that "[t]he California court's order here, which provided that custody of the child be returned to the biological mother, obviously falls within [the definition of a "custody determination' for purposes of the UCCJA]."158 The court then retrieved itself, however, by holding that, under the UCCJA and the PKPA, California continued to have modification jurisdiction. ${ }^{159}$ Accordingly, it affirmed the trial court's order dismissing the custody petition.

The appellate court's discussion of the UCCJA and the PKPA was not only incorrect, but also unnecessary to the issue before the court. The California order dismissing the adoption proceeding and ordering the prospective adoptive parents to return the child to the birth mother was a final order. It was not modifiable, either in California or else-

to avoid the potential negative impact of the PKPA, which allows "significant connection" jurisdiction only when no other state has jurisdiction. See supra text accompanying note 52 .

153. In re K.R., 897 P.2d at 899.

154. See supra note 149.

155. In re K.R., 897 P.2d at $900-01$.

156. See supra text accompanying notes $60-61$.

157. See supra Part II.C. The Colorado court cited, among other sources, Adoption of Zachariah K., 8 Cal. Rptr. 2d 423 (Ct. App. 1992), and In re Adoption of Baby Girl B., 867 P.2d 1074 (Kan. Ct. App. 1994), both discussed supra note 107, as well as Gainey v. Olivo, 373 S.E.2d 4 (Ga. 1988), discussed supra notes 80-107 and accompanying text.

158. In re K.R., 897 P.2d at 900.

159. Id. 
where. The Colorado court should have given the California judgment full faith and credit as the United States Constitution requires.

IV

\section{ThE UNIFORM ADOPTION ACT}

\section{A. Introduction}

The UAA has as its "guiding principle . . . a desire to promote the welfare of children and, particularly, to facilitate the placement of minor children who cannot be raised by their original parents with adoptive parents who can offer them stable and loving homes." 160 According to the Act's Reporter, Professor Joan H. Hollinger, "the Act is premised on the belief that children's ties to the individuals who actually parent them-or who are committed to parenting them-deserve legal protection even if those ties are psychologically and socially constructed and not biologically rooted ...."161 The Act supersedes the revised Uniform Adoption Act of 1969, which has been adopted by only five states. ${ }^{162}$

The UAA holds considerable promise as a means of resolving interstate adoption conflicts. Several provisions of the Act, however, may lead to problems similar to those that have plagued the interpretation and application of the UCCJA and the PKPA. This Part discusses the conflict of laws aspects of the UAA, particularly its jurisdictional and full faith and credit provisions, and proposes modifications of problematic provisions.

\section{B. Jurisdiction}

The jurisdiction provision of the UAA, Section $3-101,{ }^{163}$ generally follows the subject matter jurisdictional bases chosen by the UCCJA, ${ }^{164}$

160. UAA Prefatory Note, 9 U.L.A. pt. 1, at 2 (Supp. 1995).

161. Joan H. Hollinger, Adoption and Aspiration: The Uniform Adoption Act, the DeBoer-Sclimidt Case, and the American Quest for the Ideal Family, 2 DUKE J. GENDER L. \& POL'Y 15, 17 (1995).

162. Revised Uniform Adoption Act (1969), 9 U.L.A. pt. 1, at 93 (Supp. 1995).

163. UAA \& 3-101, 9 U.L.A. pt. 1, at 39-40, provides in full:

(a) Except as otherwise provided in subsections (b) and (c), a court of this State has jurisdiction over a proceeding for the adoption of a minor commenced under this [Act] if:

(1) immediately before commencement of the proceeding, the minor lived in this State with a parent, a guardian, a prospective adoptive parent, or another person acting as parent, for at least six consecutive months, excluding periods of temporary absence, or, in the case of a minor under six months of age, lived in this State from soon after birth with any of those individuals and there is available in this State substantial evidence concerning the minor's present or future care;

(2) immediately before commencement of the proceeding, the prospective adoptive parent lived in this State for at least six consecutive months, excluding periods of temporary absence, and there is available in this State substantial evidence concerning the minor's present or future care;

(3) the agency that placed the minor for adoption is located in this State and it is in the best interest of the minor that a court of this State assume jurisdiction because: 
but with modifications in subsection (a)(1) that address most of the criticisms made in this Article. Thus, the UAA modifies the "home state" provision to include "a prospective adoptive parent" as one of the identified individuals with whom the child has lived-not "from birth" as the UCCJA requires, but "from soon after birth"-and who may commence adoption proceedings. ${ }^{165}$ This change means that under the UAA, unlike the UCCJA, there will be a readily identifiable "home state" in virtually all cases of nonrelative adoption of infants, and that the "home state" will be the state where the child has lived with the prospective adoptive parents. ${ }^{166}$ As noted above, ${ }^{167}$ this state is the most appropriate location to hear the matter, and it should be given priority over other states.

In addition, the UAA tracks the UCCJA in providing a "substantial evidence," a "significant connection," and an "emergency" basis for jurisdiction, tailored for use in adoption proceedings. ${ }^{168}$ While these

(i) the minor and the minor's parents, or the minor and the prospective adoptive parent, have a significant connection with this State; and

(ii) there is available in this State substantial evidence concerning the minor's present or future care;

(4) the minor and the prospective adoptive parent are physically present in this State and the minor has been abandoned or it is necessary in an emergency to protect the minor because the minor has been subjected to or threatened with mistreatment or abuse or is otherwise neglected; or

(5) it appears that no other State would have jurisdiction under prerequisites substantially in accordance with paragraphs (1) through (4), or another State has declined to exercise jurisdiction on the ground that this State is the more appropriate forum to hear a petition for adoption of the minor, and it is in the best interest of the minor that a court of this State assume jurisdiction.

(b) A court of this State may not exercise jurisdiction over a proceeding for adoption of a minor if at the time the petition for adoption is filed a proceeding concerning the custody or adoption of the minor is pending in a court of another State exercising jurisdiction substantially in conformity with [the Uniform Child Custody Jurisdiction Act] or this [Act] unless the proceeding is stayed by the court of the other State.

(c) If a court of another State has issued a decree or order concerning the custody of a minor who may be the subject of a proceeding for adoption in this State, a court of this State may not exercise jurisdiction over a procecding for adoption of the minor unless:

(1) the court of this State finds that the court of the State which issued the decree or order:

(i) does not have continuing jurisdiction to modify the decree or order under jurisdictional prerequisites substantially in accordance with [the Uniform Child Custody Jurisdiction Act] or has declined to assume jurisdiction to modify the decree or order; or

(ii) does not have jurisdiction over a proceeding for adoption substantially in conformity with subsection (a)(1) through (4) or has declined to assume jurisdiction over a proceeding for adoption; and

(2) the court of this State has jurisdiction over the proceeding.

(Alterations in original).

164. UCCJA § 3(a), 9 U.L.A. pt. I, at $143-44$ (1988).

I65. UAA \& 3-101(a)(1), 9 U.L.A. pt. 1, at 39-40.

166. In Baby Boy Rogers's case, this provision would have identified the District of Columbia as the child's "home state," assuming that the Platts could qualify as "prospective parents" once the mother had revoked her consent. See supra text accompanying notes 54-72.

167. See supra Part III.A.1.

168. UAA \& 3-101(a)(2)-(a)(4), 9 U.L.A. pt. 1, at 40. For the text of these subsections, see supra note 163. 
jurisdictional provisions fit comfortably within the UCCJA, their counterparts in the UAA are not entirely harmonious. In addition, the "emergency" basis of jurisdiction may open the door to serious jurisdictional abuses. ${ }^{169}$

Subsection (a)(2), like its counterpart provision in the UCCJA, was designed for use in situations where there is no home state or where the proceeding was not commenced in the home state. The UAA provision confers jurisdiction over an adoption proceeding upon a state where a prospective adoptive parent lived in the state for at least six months immediately before the adoption proceeding is commenced, and there is available in the state "substantial evidence concerning the minor's present or future care." Subsection (a)(2) does not, however, require a nexus between these two criteria: all that is required is the presence of the prospective adoptive parent for the necessary period and the availability of the evidence concerning the child's care. There is no requirement that the prospective adoptive parent and the child have interacted in any way.

The counterpart UCCJA provision, on the other hand, requires not only that the requisite "substantial evidence" be available in the state asserting jurisdiction over a custody proceeding, but also that the child and at least one contestant "have a significant connection" with the state. ${ }^{170}$ The point is not that the presence of the child should be necessary to confer jurisdiction over an adoption, but rather that there should be some nexus between the child and the prospective adoptive parent such that the evidence concerns the child's present or future care in that parent's home. That nexus is provided in the UCCJA provision by adding the "significant connection" requirement to the "substantial evidence" criterion. Once that point has been established, the nexus might continue even if the child is no longer living with the parent. Such a situation is not uncommon in the context of divorce proceedings, where one spouse may leave the family home with the child and return to a former state of residence or to a family second home, or establish a home in a new state, only to have the other spouse surreptitiously remove the child and return to the state of family residence. In such cases, the leave-taking spouse will be living apart from the child in a state that has both a significant connection with the child and a substantial body of available evidence about the child's care. Such a state

169. Subsection (a)(3) does provide a clear alternative basis for jurisdiction: it permits the state where the agency that placed the child for adoption is located to preside over the adoption. UAA art. 3 , pt. $1 \mathrm{cmt}$., 9 U.L.A. pt. 1 , at 39 . This subsection, unlike subsection (a)(2), requires both that the child and either the prospective adoptive parent or the birth parents have a "significant connection" with the state, and that a substantial body of evidence concerning the child's present or future care be available in the state. UAA § 3-101(a)(3), 9 U.L.A. pt. 1, at 40.

170. UCCJA $\S(a)(2), 9$ U.L.A. pt. 1, at 143 (governing revocation of consent). 
could provide an alternative to the "home state" as a forum for jurisdiction over the divorce custody dispute.

An analogous pattern might occur in the context of an interstate adoption in the case of a delayed placement, where the mother does not decide immediately to surrender the child for adoption. Thus, if the child has lived from birth with the mother but, before attaining the age of six months, goes to live with a relative or is placed temporarily in foster care, and remains in that placement for several months before an adoptive placement occurs, the prospective adoptive parents would not have lived with the child "from soon after birth," and their state of residence, even if it is the same state in which the child lived with the birth mother, would not qualify as the home state under subsection (a)(1). Nor would the jurisdictional problem be resolved if the child were placed with the prospective adoptive parents in order to trigger the six months period "immediately before commencement of the proceeding" under subsection (a)(1), for section 3-302 requires that the adoption petition be filed no later than 30 days after placement. ${ }^{171}$ Under subsection (a)(2), both problems are solved, for the state of the prospective adoptive parents' residence would have subject matter jurisdiction based on their residence in the state for six months plus the availability of the requisite "substantial evidence" in the state, while the 30 day filing period could be honored dating from the child's placement.

Moreover, in such a case, the missing nexus between the child and the prospective adoptive parents would be supplied by the filing requirement of section 3-202, which ensures that the child is living in the home of the prospective adoptive parents, and evidence concerning the child's care in that home will be available when the hearing on the adoption petition occurs, normally several months after placement. The Commissioner's Comment to section 3-101 discusses at length the "home state" provision of subsection (a)(1), ${ }^{172}$ but sheds no light on what the drafters had in mind for subsection (a)(2). The Comment might be expanded to include an example such as that given above, or at the very least, to provide a cross-reference to section 3-302.

Subsection (a)(4), dealing with "emergency" jurisdiction, is highly problematic. As Professor Bodenheimer explained, its counterpart in the UCCJA was intended to be an extremely narrow provision that authorized a court having no other contact with the parents or the child to issue orders necessary to protect the child in an emergency: "For example, suppose a case in which a child's parents are killed in an accident away from home and the child survives. A court in the state of the

171. UAA § 3-302, 9 U.L.A., pt. 3, at 44.

172. UAA art. 3, pt. 1 cmt., 9 U.L.A. pt. 1, at 39. 
accident has jurisdiction to place the child into a temporary home."173 The UCCJA did not envision courts using emergency jurisdiction to enter initial decrees in divorce child-custody proceedings. Yet the UAA confers upon such courts jurisdiction to entertain adoption proceedings. The danger of making this option available can be seen clearly by examining a recent case decided by the Arizona Supreme Court, J.D.S. v. Franks, ${ }^{174}$ which carried the distortion of the UCCJA's jurisdictional scheme to new heights by holding that the state of the prospective adoptive parents' residence might assert jurisdiction under the emergency clause of the Act.

In J.D.S., the birth parents had lived together briefly in Arizona, but had separated prior to the child's birth there on August 8, 1993. The mother, K.W., cared for her daughter until November 22, when she relinquished the child for adoption. The mother's attorney worked with the Arizona and Florida administrators of the Interstate Compact for the Placement of Children (ICPC) to place the baby with G.H. and K.H. in Florida. The prospective adoptive parents filed a petition for adoption in Florida on November 30. Meanwhile, the biological father, J.D.S., learned from the mother on December 3 that she had placed the child for adoption. He filed a petition for habeas corpus in Arizona on December 7. ${ }^{175}$

The Arizona trial court, eschewing the UCCJA, chose to rely on the ICPC as the appropriate jurisdictional source. The court held that it lacked jurisdiction over the prospective adoptive parents and denied the habeas writ. The Arizona Court of Appeals vacated the trial court's order and applied the UCCJA. It concluded that Arizona was both the child's "home state" and the state with the closest connection to the child, and therefore instructed the trial court "to take all necessary measures to secure the return of the child to the State of Arizona."176

The Arizona Supreme Court managed to conclude that Arizona "had been the child's home state within 6 months before the commencement of the proceedings," 17 despite the fact that the child had not remained in Arizona for the entire six months as required by the Act. The supreme court went on to acknowledge that both Arizona and Florida had a "significant connection" with the child. It nevertheless decided that Arizona's connection was more significant than Florida's, because both of the birth parents resided in Arizona and the mother's testimony would be relevant to the issue of the father's ability to care

173. Bodenheimer, supra note 41, at 993.

174. 893 P.2d 732 (Ariz. 1995).

175. Id. at 735-36 \& n.2.

176. J.D.S. v. Superior Court, 893 P.2d 749, 758 (Ariz. Ct. App. 1994), quoted in J.D.S. v. Franks, 893 P.2d at 736.

177. J.D.S. v. Franks, 893 P.2d at 741 . 
for the child. Having reached this conclusion, however, the court still chose to defer to the Florida court because the Florida proceeding had been commenced first, was in compliance with the ICPC, and-here's the kicker-because the Florida court was exercising jurisdiction pursuant to the emergency jurisdiction provision of the UCCJA. ${ }^{178}$

The Arizona Supreme Court explained that the emergency jurisdiction clause was available because a Florida pediatrician who had examined the baby shortly after her arrival in Florida described her condition as "a classic medical picture of child neglect": she was underweight and had severe diaper rash. ${ }^{179}$ The physician further stated that the child was "in severe jeopardy should she return to the environment in Arizona that allowed such a condition to develop." 180 Based on this evidence, the Arizona court concluded that the Florida trial court could have exercised emergency jurisdiction under the Act. ${ }^{181}$

The court then held that Arizona could properly defer to Florida on the basis that Florida was exercising emergency jurisdiction, even though the child's physical condition that had been characterized as the "emergency" had long since been corrected, and despite the fact that the child had not been in the father's care when the neglect occurred. The court stated:

We conclude that Florida was exercising jurisdiction substantially in conformity with the UCCJA. Therefore, the Arizona trial court did not abuse its discretion by deferring to the Florida trial court, even though the Arizona trial court also had jurisdiction. Florida could properly have exercised jurisdiction pursuant to the emergency jurisdiction provision, in compliance with both the UCCJA and the PKPA. Arizona could have exercised jurisdiction based on the significant connection provision or the home state and domicile provision. ${ }^{182}$

This interpretation of the UCCJA - that a state with jurisdiction under one of the two overlapping primary jurisdictional grounds should defer to a state exercising emergency jurisdiction-is most unfortunate, because it unduly expands the limited role of emergency jurisdiction under the Act. Moreover, the Arizona court's reliance on the ICPC as a source of jurisdiction is particularly unfortunate. The ICPC is not an adoption statute, but rather a uniformly agreed-upon set of practices for the placement of children. ${ }^{183}$

178. Id. at 743 .

179. Id. at 736.

180. Id. at 743 .

181. Id.

182. Id. at 745 .

183. See Bernadette W. Hartfield, The Role of the Interstate Compact on the Placement of Children in Interstate Adoption, 68 NEB. L. Rev. 292, 293, 296-97 (1989). 
A correct analysis of the UCCJA and the PKPA in J.D.S. would have been to hold neither Act applicable. Florida was proceeding properly under its own adoption statute. Once the father filed for habeas in Arizona, the adoption could not proceed under Florida law without either obtaining his consent or terminating his parental rights. Initially, a jurisdictional impasse was created: Arizona lacked in personam jurisdiction over the prospective adoptive parents, while Florida lacked in personam jurisdiction over the father. By the time of the Arizona Supreme Court decision, however, the father had appeared in the Florida proceedings, and the Court correctly observed that his "due process rights will be protected in Florida just as they would be in Arizona."184 That observation should have rendered the other matters moot. Certainly it reduces them to dicta that can be safely ignored by other courts.

As written, the emergency provision of the UAA appears to validate the unfortunate reasoning used in J.D.S. Unless the section is redrawn to limit its scope to authorize a court merely to issue temporary orders needed to take care of a true emergency rather than to assume jurisdsiction over the adoption proceeding, or better still, omitted entirely as superfluous, there is grave danger that the subsection will lend itself to an end-run around the preferable "home state" provision in (a)(1).

Finally, subsection $(a)(5)$ contains a default provision when no other state would have jurisdiction under subsections (a)(1) through (a)(4). ${ }^{185}$ This section appropriately rounds out the UAA's menu of subject matter jurisdiction.

Because adoption orders are not modifiable, the UAA appropriately does not distinguish between "initial" jurisdiction and "modification" jurisdiction. The UCCJA imposed this distinction in order to preserve the primacy of the state exercising initial jurisdiction to continue to supervise its decree until that state had relinquished its jurisdiciton or declined to act. No similar ongoing supervision is expected of an adoption court. Once an adoption is ordered, the newly created family has the same legal status as a family composed of birth parents and their child. If further orders touching the family are required, such as orders under "open adoption" laws governing visitation between the adoptive child and its birth grandparents, for example, these proceedings should be commenced according to the state's local family law provisions, not under the UCCJA. Of course, if the adoptive parents

184. J.D.S. v. Franks, 893 P.2d at 746. A way of resolving the jurisdictional impasse that would have resulted had the father not voluntarily appeared in the Florida proceedings is suggested supra in text accompanying notes 140-141.

185. UAA § 3-101(a)(3), (a)(5), 9 U.L.A. pt. 1, at 40. For the text of these subsections, see supra note 163. 
should divorce, and one of them should remove the child to another state, the UCCJA would be applicable. It would be applicable, however, because the divorce proceeding might give rise to an interstate child custody dispute, not because the child had been adopted.

Subsections 3-101(b) and (c) ${ }^{186}$ deal with adoption proceedings that are commenced after a "custody proceeding" under the UCCJA has already begun. Subsection 3-101(b), dealing with pending proceedings, gives priority to the proceeding commenced first, unless that proceeding is stayed by the court in which it is pending. Subsection 3-101(c), dealing with proceedings in which a custody decree had already been entered when the adoption proceeding was commenced, gives priority to the court that entered the custody determination.

These provisions should help reduce some of the potential conflicts that arise from the overly broad interpretations of the UCCJA discussed earlier in this Article. ${ }^{187}$ Recall, for example, the facts of Souza $v$. Superior Court. ${ }^{188}$ The Hawaii divorce court had assumed jurisdiction over the question of custody of the parties' daughter under the UCCJA. After the mother, who had been awarded custody, moved to California and remarried, she and the stepfather commenced a stepparent adoption in California. The Hawaii court, notified of this proceeding by the father, who continued to live in Hawaii and who had been given visitation rights, declared itself to be exercising jurisdiction in conformity with the UCCJA. California then deferred to Hawaii's continuing jurisdiction.

California's decision is consistent with UAA Section 3-101(c), for Hawaii was continuing to exercise jurisdiction substantially in accordance with the UCCJA. Hawaii, however, did not have jurisdiction over the adoption proceeding under the UAA: the Act does not confer jurisdiction on a state where one birth parent lives apart from the child, even if that state qualified as the child's home state at the time when the UCCJA proceeding was commenced. ${ }^{189}$ Indeed, unless the birth father consents or is deprived of his parental right to object, the stepparent adoption cannot proceed anywhere. ${ }^{190}$ Hawaii can, however, determine whether the father's consent will be dispensed with on the ground that he had abandoned his daughter. ${ }^{191}$ If Hawaii determines that he did, this information can be provided to the court in California and that court can proceed with the stepparent adoption.

186. See supra note 163.

187. See supra Part II.C.

188. 238 Cal. Rptr. 892 (Ct. App. 1987). For a discussion of Souza, see supra text accompanying notes $86-90$.

189. UAA § 3-101(c), 9 U.L.A. pt. 1, at 40. For the text of this subsection, see supra note 163.

190. See UAA $\$ \S 2-401$ to $-402,9$ U.L.A. pt. 1, at 27-30 (stating prevailing law).

191. Souza, 238 Cal. Rptr. at 895-96. 
A superior system would be to modify the UAA so as to include an enabling provision, analogous to URESA, as suggested above. ${ }^{192}$ The proceeding could then be handled cooperatively by both states. The UAA can be amended to accommodate this procedure, either by the Commissioners or by individual states in the process of adopting the Act.

\section{Finality}

The UAA's finality provisions are sound. Unfortunately, the commentary attached to those provisions draws attention to a case that may mislead courts facing conflict of laws problems. Section 3-706 properly makes clear that a decree ordering an adoption is a final order, ${ }^{193}$ and section 3-707 provides that such a decree cannot be challenged after six months from the date the decree is issued. ${ }^{194}$ Both provisions effectively carry out the drafters' expressed intent to promote "the integrity and finality of adoptions." 195 If the adoption decree is denied, section 3-704 instructs the court to dismiss the proceeding "and issue an appropriate order for the legal and physical custody of the minor."196 If the petition is denied because a parent's consent has been withdrawn or a relinquishment set aside, the court must proceed under sections $2-408$ or $2-409$, which govern withdrawal of consent and relinquishment. ${ }^{197}$ Section 3-704 then provides that "[i]f the petition for adoption is denied for any other reason, the court shall determine the minor's custody according to the best interest of the minor." 198 The accompanying Comment clarifies that this provision is intended to authorize the court to grant custody to "the individuals who had hoped to adopt... even though they cannot become the legal adoptive parents."199

This proposition, while no doubt controversial, is defensible as a matter of interual state adoption law. One of the cases cited by the Comment in support of this proposition, however, is highly questionable from the perspective of conflict of laws, and warrants brief discussion. In Lemley v. Barr, ${ }^{200}$ a child was invalidly relinquished for adoption in Ohio. The child was placed for adoption with a West Virginia couple. Within a matter of weeks, the birth mother sought the return of her

192. See supra text accompanying notes 140-141.

193. UAA § 3-706, 9 U.L.A. pt. 1, at 63.

194. UAA § 3-707, 9 U.L.A. pt. 1, at 63.

195. UAA Prefatory Note, 9 U.L.A. pt. 1, at 2.

196. UAA § 3-704, 9 U.L.A. pt. 1, at 61 .

197. Id.

198. Id.

199. UAA \$ 3-704 cmt., 9 U.L.A. pt. 1, at 62.

200. 343 S.E.2d 101 (W. Va. 1986). 
child, but was unsuccessful. She and her parents commenced a habeas corpus action in Ohio against the unknown custodians of the child and the two Ohio attorneys who had accepted the relinquishment.

The Ohio courts ultimately sustained the mother's position and ordered the identity of the prospective parents revealed. The mother and her parents thereupon commenced a habeas corpus action in West Virginia, asking that the child be returned pursuant to the Ohio judgment. The West Virginia Supreme Court of Appeals correctly recognized that the Ohio court had established jurisdiction over the West Virginia couple and that its judgment setting aside the mother's consent was entitled to full faith and credit. ${ }^{201}$ Despite the clear implications of this holding that the West Virginia courts should respect the disposition reached by the Ohio courts, the West Virginia Supreme Court also decided that it was justified in placing "the equitable rights of Ryan above the legal rights of his mother." 202 Accordingly, it remanded the matter "for a determination of what physical custody arrangement is in Ryan's best interests." 203

The West Virginia court noted that it could "modify so much of the Ohio Court of Common Pleas judgment as relates to physical custody," citing two West Virginia Code sections that embody the jurisdiction and modification provisions of the UCCJA. ${ }^{204}$ This citation, however, was misplaced. The West Virginia court was not proceeding under the UCCJA: it was deciding a habeas corpus proceeding. Nor did it have authority to modify the Ohio order, unless that order was modifiable in Ohio. Certainly the UCCJA did not confer such authority. As we have seen, ${ }^{205}$ in Ohio the writ of habeas corpus tests only the legal right to custody, not the future welfare of the child. The Lemley court made the same mistake in interpreting Ohio law on this point that the New Jersey court in E.E.B. v. D.A. ${ }^{206}$ made four years earlier. Neither court was on sound ground in relying on the UCCJA to hold a "best interests" custody hearing once the Ohio courts had issued the writ of habeas corpus. Both courts should have deferred to Ohio to entertain a custody petition, assuming that Ohio law would have conferred standing upon the petitioners.

Lemley is not strong support for the position taken in section 3704. The "best interests" hearing that it advocates following the denial

201. Id. at 105-08.

202. Id. at 109. At the time rehearing was granted, Ryan was five years old.

203. Id.

204. Id. at 109 n.10 (also citing Justice Frankfurter's concurring opinion in May v. Anderson, 345 U.S. 528 (1953), discussed supra in text accompanying notes 123-125).

205. See supra text accompanying notes 131-133; see also May, 345 U.S. at 532.

206. 446 A.2d 871 (N.J. 1982), cert. denied, 459 U.S. 1210 (1983); see supra text accompanying notes 91-106. 
of an adoption petition should be confined to cases that do not present full faith and credit problems. The Comment cites two such cases:207 one from California ${ }^{208}$ the other from New Jersey. ${ }^{209}$ If states adopt the final sentence of section 3-704, thus permitting "best interests" hearings following the denial of an adoption petition, then other courts will be authorized to treat their decrees in the same way. Presumably, although the UAA is not explicit, orders entered following such "best interests" hearings will be custody decrees and, as such, modifiable during the child's minority as circumstances change.

\section{Recognition}

As to recognition, the UAA provides in part in section 1-108 that an adoption decree issued by another state court that is entitled to full faith and credit will have the same effect as a decree issued in the recognizing state. ${ }^{210}$ This position is entirely correct and most welcome. The accompanying comment, which adds that "[a] final decree or order of adoption is entitled to full faith and credit either under Article 4, Section 1 of the U.S. Constitution or under the Parental Kidnapping Prevention Act"211 should, however, be revised to omit the superfluous and misleading reference to the PKPA. The Full Faith and Credit Clause is all the authority needed to do the job of recognition in the context of adoptions. The PKPA should be limited to modifiable decrees of child custody.

The UAA, like the UCCJA, adopts the position that personal jurisdiction over the absent parties is unnecessary. For reasons spelled out above, ${ }^{212}$ I believe this conclusion may be on weaker constitutional ground in the case of the UAA than in the UCCJA, but I have suggested a revision to the UAA-a URESA-like enabling provision-that may resolve this infirmity. ${ }^{213}$ With these changes, the conflict of laws aspects of the UAA would fit smoothly with its substantive provisions.

\section{CONCLUSION}

No one who reads the cases discussed in this Article can doubt the truth of the observation voiced by the district court in Baby Jessica's case: "the court is under no illusion that this tragic case is other than an unbelievably traumatic event." ${ }^{214}$ Most of this tragedy and trauma

\footnotetext{
207. UAA \& 3-704 cmt., 9 U.L.A. pt. 1, at 62.

208. Adoption of Kelsey S., 823 P.2d 1216 (Cal. 1992).

209. Sorentino v. Family \& Children's Soc'y, 378 A.2d 18 (N.J. 1977).

210. UAA § 1-108, 9 U.L.A. pt. 1, at 10.

211. Id. at 10-11.

212. See supra text accompanying notes 136-139.

213. See supra text accompanying notes 140-141.

214. In re B.G.C., 496 N.W.2d 239, 246 (Iowa 1992) (quoting the district court).
} 
arises from the substantive law of adoption. That is a subject beyond the scope of this Article, though it is addressed by the "substantive" sections of the Uniform Adoption Act. ${ }^{215}$

The UAA's "procedural" provisions, touching the conflict of laws issues discussed in this Article, are basically sound. The problems identified in this Article created by misuse of the UCCJA's "home state" provision have been solved by tailoring that concept to fit the pattern of adoption cases, rather than child custody proceedings following divorce. The unresolved question of personal jurisdiction that lingers in the aftermath of May v. Anderson ${ }^{216}$ can be handled in the interstate adoption context as it was earlier handled in interstate support situations-by the cooperative model pioneered in the URESA. The potential source of jurisdictional mischief represented by the UAA's emergency jurisdiction provision can be contained by limiting its scope to temporary orders. The UAA's superfluous reliance on the PKPA can be deleted. These criticisms are, for the most part, details that are easily remedied in the process of state-by-state adoption.

While state legislatures consider enactment of the UAA, however, state courts can lessen some of the trauma in interstate cases like Baby Jessica's by taking a less expansive view of the UCCJA and the PKPA. As this Article has shown, these Acts were not intended to apply to adoption proceedings, are not suitable for handling adoption proceedings, and should not be construed to apply to adoption proceedings. Rather, the UCCJA and the PKPA should be limited to the purpose for which they were created: to bring stability to children involved in interstate divorce and separation proceedings. If that purpose is accomplished, we should no longer see pictures of toddlers caught between battling parents-either in divorce cases or in adoption cases-on the cover of Time.

215. Professor Joan H. Hollinger, the Reporter for the UAA, has written that had the UAA been applied to Baby Jessica's case, the matter might have been resolved much earlier and with much less difficulty for all concerned. See Hollinger, supra note 161, at 20.

216. 345 U.S. 528 (1953). The point seems to have been resolved for purposes of the UCCJA. See, e.g., Fitzgerald v. Wilson, 46 Cal. Rptr. 2d 558, 564 (Ct. App. 1995) ("[T] he UCCJA does not require personal jurisdiction over a nonresident parent before the court may determine child custody issues. Indeed, such a requirement would thwart the purpose of the act, which is to provide a forum to resolve custody issues."). 
